Portland State University

PDXScholar

\title{
The ion-exchange chromatographic separation of the components of the product mixture resulting from reaction of trans-dichlorobis (ethylenediamine) cobalt (III) chloride with thiocyanate ion
}

William Trew Jordan

Portland State University

Follow this and additional works at: https://pdxscholar.library.pdx.edu/open_access_etds Let us know how access to this document benefits you.

\section{Recommended Citation}

Jordan, William Trew, "The ion-exchange chromatographic separation of the components of the product mixture resulting from reaction of trans-dichlorobis (ethylenediamine) cobalt (III) chloride with thiocyanate ion" (1967). Dissertations and Theses. Paper 377.

https://doi.org/10.15760/etd.377

This Thesis is brought to you for free and open access. It has been accepted for inclusion in Dissertations and Theses by an authorized administrator of PDXScholar. Please contact us if we can make this document more accessible: pdxscholar@pdx.edu. 
AN ABSTRACT OF THE. THESIS OF

William Trew Jordan for the Master of Arts Degree in Chemistry

Date thes is is presented: August 9, 1967

Title: The Ion-Exchange Chromatographic Separation/of the

Components of the Product Mixture Resulting From Reaction of

Trans-Dichlorobis (Ethylenediamine)Cobalt (III) Chloride with

Thiocyanate Ion.

Abstract approved:

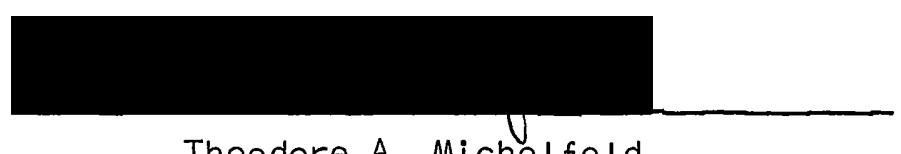

Theodore A. Michelfeld

Major Professor 
THE ION-EXCHANGE CHROMATOGRAPHIC SEPARATION OF THE COMPONENTS

OF THE PRODUCT NIXTISE RESULTING FROM REACTION OF

TRANS-DI CHLOROBIS (ETHYLENEDIAMINE) COBALT(IIJ) CHLORIDE

NITH THIOCYANATE ION

by

William Trew Jordan

ABSTRACT

The object of the research was to study, by means of ion-exchange chromatography, the product mixture resulting from reaction of trans$\left[\mathrm{Co}(e n)_{2} \mathrm{Cl}_{2}\right] \mathrm{Cl}$ and $\mathrm{SCN}^{-}$. Cis- and trans- $\left[\mathrm{Co}(e n)_{2}(\mathrm{NCS}) \mathrm{Cl}\right] \mathrm{Cl}$ had previously been obtained as products of this reaction. However, the possibility of the presence of other products consistent with the nature of the reactants could not be dismissed. These include the dichloro, dithiocyanato, and aqua complexes.

The constituents of the solution resulting from the reaction were separated on a column of Dowex $50 \mathrm{~W}-\mathrm{X} 8$ resin by elution with hydrochloric acid. The eluted fractions were evaporated at room temperature in order to obtain crystals to be used for infrared spectral analysis and identification. Three primary fractions were exided from the column. The first, eluted with $0.5 \mathrm{M} \mathrm{HCl}$, was identifieci as trans$\left[\mathrm{Co}(\mathrm{en})_{2}\right.$ (NCS)CI] Cl by analysis of the infrared spectrum. Two types of crystals were obtained from the second fraction which was eluted with $1 \mathrm{Ni} \mathrm{HCl}$. The first crystals to form in this solution were orange in color and were identified by examination of the infrared spectrum 
as cis- $\left[\mathrm{Co}(e n)_{2}(\mathrm{NCS}) \mathrm{Cl}\right] \mathrm{Cl}$. The second crystals obtained from the same fraction were shown to be cis- $\left[\mathrm{Co}(\text { on })_{2}(\mathrm{NCS}) \mathrm{Cl}\right] \mathrm{Cl}$. The crystals isolated from the third fraction, eluted with $3 \mathrm{M} \mathrm{HCl,} \mathrm{were} \mathrm{also}$ identified as cis- $\left[\mathrm{Co}(\text { on })_{2}\right.$ (NCS) Cl] $\mathrm{Cl}$.

On the basis of observations of the column elution and an analysis of the ultraviolet spectra of the eluted fractions, it was concluded that band \#2 was cis-[Co(en) 2 (NCS)Cl] $\mathrm{Cl}$ and band \#3 was cis$\left[\mathrm{Co}(e n)_{2}(\mathrm{NCS})\left(\mathrm{H}_{2} \mathrm{O}\right)\right] \mathrm{Cl}_{2}$. Aquation of $\mathrm{cis}-\left[\mathrm{Co}(\text { en })_{2}(\mathrm{NCS}) \mathrm{Cl}\right]^{+}$was observed to occur on the column as well as in the oluted solution. In addition, rechlorination of the aquated compound was found to occur in the eluted fraction so that after olution the second and third fractions were mixtures of the unaquated and aquated complexes.

No crystals of dithiocyanato or dichloro compounds were obtained in the separation so that the reaction was demonstrated to be essentially 1:1 between the complex and thiocyanate. Trans$\left[\mathrm{Co}(\mathrm{en})_{2}\right.$ (NCS)Cl] $\mathrm{Cl}$ was found to comprise forty-nine percent of the typical product mixture. Since other products were present only in very low concentrations, the combined cis- $\left[\mathrm{Co}(\text { on })_{2}(\mathrm{NCS}) \mathrm{Cl}\right] \mathrm{Cl}$ and cis$\left[\mathrm{Co}(e \mathrm{n})_{2}(\mathrm{NCS})\left(\mathrm{H}_{2} \mathrm{O}\right)\right] \mathrm{Cl}_{2}$ contents was estimated at roughly fifty mole pericent. 
APPROVED:
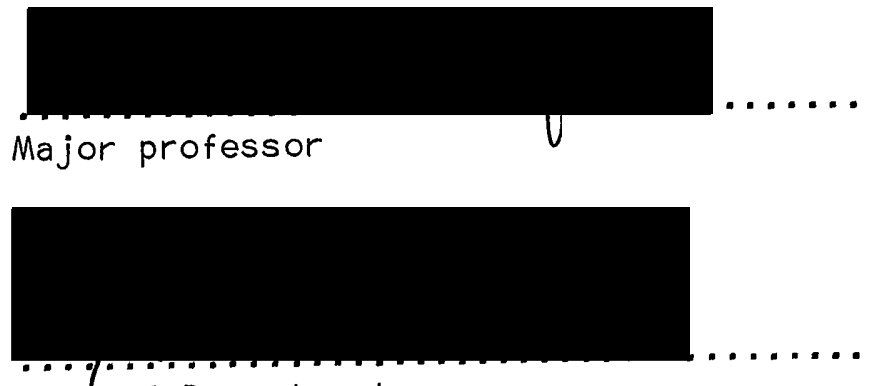

Head of Department

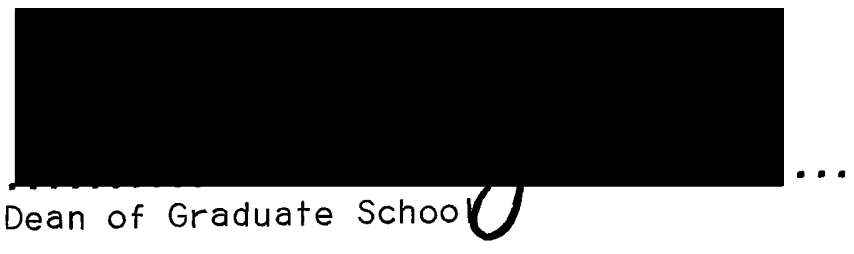

Angust 9 1967

Date thesis is presented 
THE ION-XXHANGE CHROMATOGRAPHIC SEPARATION OF THE COMPONENTS OF THE PRODUCT MIXTURE RESULTING FRON REACTION OF TRANS-DICHLOROBIS (ETHYLENE IAMTNE) COBALT (III) CHLORTDE WITH THIOCYANATE ION by Whlllem Trew Jordan

\author{
A THESIS \\ Presented to the Graduate Faculty \\ of Portland state college \\ In Partlal Fulflliment of Requlrements \\ For the Degree of Master of Arts \\ Department of Chamistry
}

Under the Superviston of Dr. Theodore A, Michelfeld

Portland, Oregon

August 9,1967 
ACKANOWLOCOENT

The author wishes to express his gratitude to Dr. Theodore A. Michelfeld for direction of the rasearch and help in preparing the thesis. He is grateful to Dr. Horace F. White and Dr. Dennis W. Barnum for techileal advice, and to Mrs. Kenneth Jordan who typed the text.

This thesis is dedicated with love to my wife, Vick1. 
TABLE OF CONTENTS

Page

INTRODUCTION ............................. 1

I. OBJECTIVE OF THE RESEARCH ................ 1

I1. ION EXChANGE ......................... 1

III. INFRARED SPECTRA .................... 7

IV. THE REACTION ..................... 10

EXPERIMENTAL .......................... 12

I. INTRODUCTION TO THE EXPERIMENTAL WORK ........ 12

II. PREPARATION OF THE STARTING COMPOUND .......... 13

III. THE REACTION BETWEEN TRANS-[Co(en) $\left.{ }_{2} \mathrm{Cl}\right] \mathrm{Cl}$ and $\mathrm{SCN}^{-}, * 14$

IV. ION-EXCHANGE SEPARATION ................ 14

V. ISOLATION OF CRYSTALS .................. 19

VI. INFRARED SPECTRA ......., $\ldots, \ldots, \ldots$

VII. ANALYSIS OF THE ULTRAVIOLET SPECTRA,,$\ldots 6$

VIII. ESTIMATE OF TEE IRANS- $\left[\right.$ CO(On) ${ }_{2}$ (NCS)CI]CI CONTENT

OF THE PRODUCT MIXTURE .............. 44

IX. ANALYSIS FOR COBALT BY ELECTROOEPOSITION . . . . . . 47 DISCUSSION OF THE EXPERIMENTAL RESULTS . . . ........ 49 sumary ................................. 55

BIBLIOGRAPHY ............................, 56 


\section{INTRODUCTION}

I. Objective of the Research

In recent years the technique of Ion-exchange chromatography has found useful application in the area of coordination chemistry. Previous experimenters ${ }^{1-7}$ have separated geometrical (cis/trans) 1somers and performed diaplacement reactions on lon-exchange columns. It has been the primary objective of the present research to extend the applicability of 1on-exchange chromatography to an analysis of product mixtures resulting from reactions which produce coordination compounds.

The Initial plan called for the study of a serles of reactions originally carried out in the beginning of the twentieth century by the noted Swiss chemist Alfred Werner. ${ }^{8}$ The work herein discussed has been confined to one of these reactions, namely that between transdichlorobig(ethylenediamine)cobalt (III) chloride and thiocyanate ion. Spectfically, the problem has been to determine what is obtained when the mixture resulting from the above reaction 18 poured onto an 1onexchange column and then eluted with a sultable solvent. It was hoped that some knowledge of the composition of the product mixture might thereby be gained. That such an effort has, in some measure, been successful is the thesis of this paper.

II. Ion Exchange

The term ion exchange is basically self-explanatory, referring simply to the replacement of one ion by another in association with a 
counter ion. This relatively simple concept, however, forms the basis for an Impressive number of chemical separations, displacement reactions, and analytical schemes, and is responsible for the existence of a large body of highly developed theory.

While Moses 9 and Aristotle ${ }^{10}$ have been cited by the most scrupulous of historians as the first to recognize and take advantage of the principles Involved in ion exchange, it appears that the origin of modern Inquiry into ion-exchange phenomena can be traced to mid-nineteenth century England with the discovery of base or cation exchange in soil. In 1845 an English chemist named Spence was hired by landowner H. S. Thompson to find out why anmonla was disappearing from his manure heaps. 11 when spence poured an ammonium sulfate solution through a column packed with soil, calcium sulfate was present in the solution emerging at the lower end. A thorough study of this phenomenon was undertaken in 1850 by J. T. Way ${ }^{12}$ who attributed these cation-exchanging properties to the clay or alumino-silicate portion of the soi1. The findings of Way and Spence paved the way for further work and, in 1907, Gans, ${ }^{13}$ a German chemist, introduced a synthetic alumino-silicate gel to be used for water-softening.

A momentous step in the evolution of ion exchangers was taken in 1935 when two English chemists, B. A. Adams and E. L. Holmes, ${ }^{14} \mathrm{~d} 1 \mathrm{~s}-$ covered that certain bakelite resins (in this case crushed phonograph records) could exchange cations. They showed that the lon-exchanging properties of these materials were due to the presence of phenolic -OH groups which, under conditions of sufficiently high $\mathrm{pH}$, could exchange hydrogen ion for another cation. Adams and Holmes proceeded to 
synthesize a more efficient resin containing the more acidic sulfonic acid groups, which proved to be the forerunner of one of the most frequently used modern lon-exchange resins.

A typical modern ion-exchange resin is Dowex 50W- $\times 4$, which was employed in the work presented in this paper. Dowex $50 \mathrm{~W}-84$ is one of a number of crosslinked polystyrene resins which owe their lon-exchanging properties to the presence of sulfonic acid groups. 15

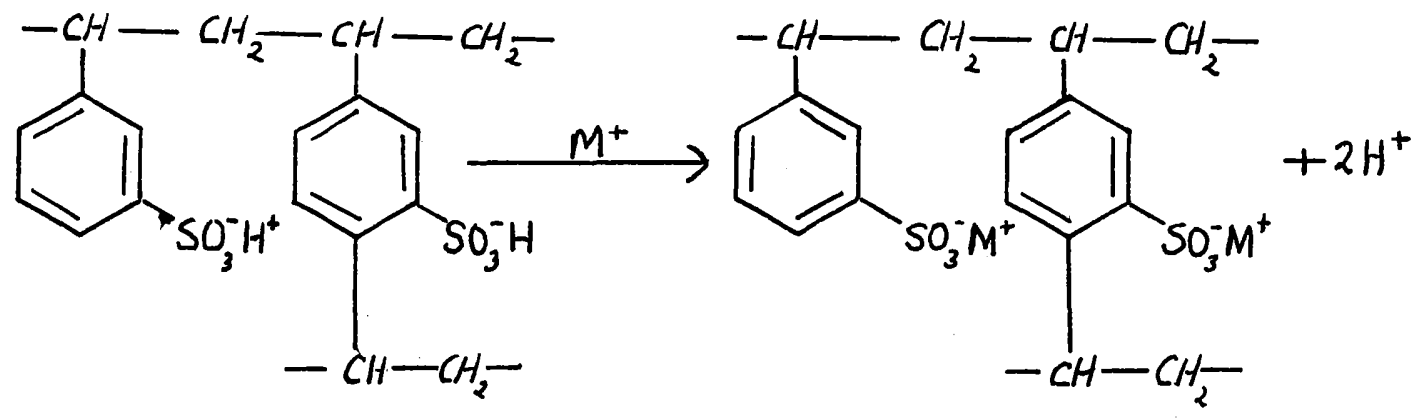

Resins of this type are prepared by polymerizing styrene using divinylbenzene as a crosslinking agent.<smiles>C=Cc1ccccc1</smiles>

and then sulfonating with oulfurle or chlorosulfonic actd.

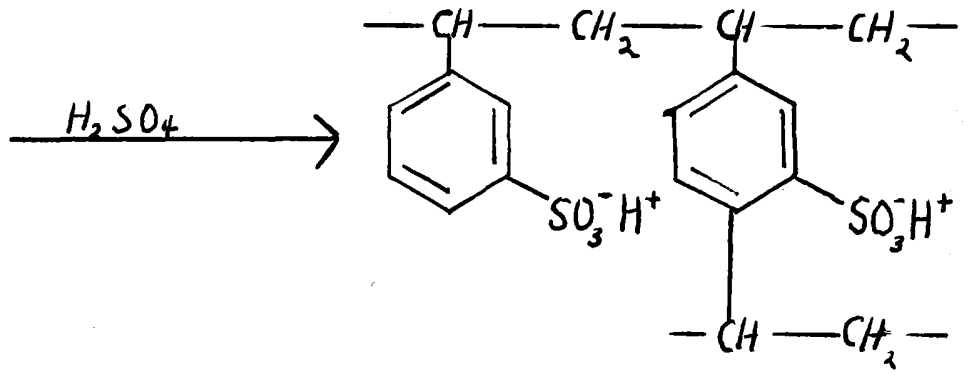


The degree of crosslinking can be controlled by adjusting the amount of divinylbenzene used. Crosslinking is a necessity since straight chain polyelectrolytes are soluble whereas crosslinked polymers are insoluble, and for most purposes an ion exchanger must be in the solld state. Too much crosslinking not destrable, however, since the resin must be able to swell in order to accomodate different sized Ions and facilitate the mobility of exchanging Ions. 16 Generally, a wide selection of resins is avallable with varying degrees of crosslinking and acid strength. The appropriate resin is chosen for speclflc task.

That such resins may be used to separate ions in a mixture is due to the fact that different lons are attracted to a particular resin to a different degree. For example, a dipositive ion will be more strongly held by a cation-exchange resin than a monopositive ion. Even ions of the same charge will differ in the degree to which they are held by particular resin depending on relative size, internal dipole moment, effective charge, and ability of the solvent from which the ion ig extracted to attract the ion. Generally, the greater the differences in ion properties, the better the separation which can be obtained.

Chromatographic separations by means of ion exchange are usually carried out in glass columns packed with resin. Several column techniques are avallable, but the most common one for this type of work, and that which has been used here, is elution development. ${ }^{17}$ In this method, a solution containing the ions to be separated is poured onto the top of the column of resin, and as the solution begins to run 
through the resin, ions from the solution displace 1ike-charged ions in the resin at the top of the column. When all of the solution has been adsorbed onto the resin, a suitable solvent is allowed to flow through the column bed at steady rate. Solvent lons displace those of the mixture downward on the column packing, but at different rates dependIng on the relative ease of displacement of different ions. If the Ions in question absorb light In the visible region, then formation of colored bands will be observed on the column. Elution with the solvent is continued until each band has passed through the column and has been collected in separate container. Under the proper conditions complete separation of the components of the mixture may thus be obtained.

Selection of a proper resin and eluting solvent is important. It is desirable that the bands be compact and have sharp boundartes. If the solvent strength is too great or if the exchanging lon of a particular solvent is adsorbed too trongly by the resin in relation to the Ions to be separated, the bands will spread and run together and a poor separation will be obtained. On the other hand, the eluting solvent must be of sufficient strength to allow the bands to move and separate continuousiy. Optimum conditions axe arrived at by a process of trial and error, and it is not uncomon to change the strength of the eluent durling the elution.

The first reported separation of coordination compounds by ionsxchange chromatography was carried out by King and Dismukes ${ }^{1}$ in 1952. Using Dowex-50 resin they separated a mixture of the hexaquachromium(III) Ion, $\left[\mathrm{Cr}\left(\mathrm{H}_{2} \mathrm{O}\right)_{6}\right]+++$, and its mono- and disubstituted derivitives, 
$\left[\mathrm{Cr}(\mathrm{NCS})\left(\mathrm{H}_{2} \mathrm{O}\right)_{5}\right]^{++}$and $\left[\mathrm{Cr}(\mathrm{NCS})_{2}\left(\mathrm{H}_{2} \mathrm{O}\right){ }_{4}^{+}\right.$, by eluting with perchlorle acld. As expected, the lons ware luted in order of Increasing charge, the monopositive lon coming off first, and the tripositive Ion last.

Having succeeded in separating lons of different charges in this manner. King and Walters ${ }^{2}$ predicted separabllity of geometrical Isomers by lon exchange on the bas is of differences in dipole moment and went head to separate mixture of els- and trens- $\left[\mathrm{Co}\left(\mathrm{NH}_{3}\right)_{4}\left(\mathrm{NO}_{2}\right)_{2}\right]^{+}$ In this way. The trans Isomer having no net dipole mement was eluted

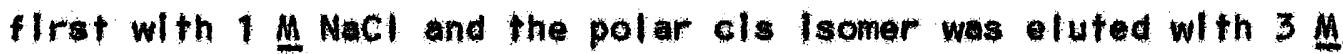
$\mathrm{NaCl}$.

Subsequently a number of Investigators have carrled out Ionexchange separatlons of gecmetrleal isomers of coordination compounds. A number of such separatlons have been performed by Morl and coworkers 3 at Kenazawa UnIversity In Japan. In 1955 they reported separation of cla- and trans- $\left[\mathrm{Co}\left(\mathrm{NH}_{3}\right)_{4}\left(\mathrm{NO}_{2}\right)_{2}\right] \mathrm{Cl}$ on an lon exchanger of the $\mathrm{RMH}_{3}$ form, and In $1956^{4}$ they used amberllte IR-120 to separete cls and trans isomers of $\left.\left[\mathrm{Co}(e n)_{2} \mathrm{Cl}_{2}\right]^{+},[\operatorname{Colen})_{2}^{(\mathrm{NCS})}\right]_{2}^{+}$, and $\left[\operatorname{Co}(e n)_{2}\left(\mathrm{NO}_{2}\right)\right]^{+}$. In 1957, Hougen, Sehlug, and $\mathrm{KIng}^{5}$ separated the prevlously unresolved cls and trans isomers of dithlocyanatotetraaquachroml um(III) lons from a mixture resulting from reaction between chromle perchlerate and potassium thlocyanate, and evaluated the relative amounts of the two Isomers in an equllibrlum $\mathrm{mixture.} \mathrm{In} \mathrm{1961,} \mathrm{DImolakis} \mathrm{and}$ Myrat ${ }^{6}$ of the Atomle Energy Commission In Athens, Greece separated cls and trans Isomers of $\left[\mathrm{Co}(\mathrm{en})_{2} \mathrm{Cl}_{2}\right] \mathrm{Cl}$ on column of Dowex 50 resin only four centimeters in length to minimize aquation. 
More recentiy, Michelfeld ${ }^{7}$, at the University of Nebraske, has carrled out the separatlons of a number of geometrleal isomer of coordination compounds and estimated the degree to which separation of each palr may be accomplished. In these and all other separatlons the trans lsomer has always been eluted first.

\section{Infrared Spectra}

Prevlous experimenters who have carrled out lon-exchange seperations of geometrleal Isemers have made use of the differences in the spectra of the specles in the vistble and ultraviolet regions for purposes of detection and estimation of the degree to which a separation had been accompllshed. The problem here has been a somewhat different one. In prevlous experiments the compounds to be separated ware prepared, purlfled, disselved, mixed and poured onto an lon-exchange column so that, unless a lde reaction occurred (perhaps on the column), It was known exactly what was present and what, therefore, would emerge upon lution. The objective of the experimental work roported here has been to determine the composition of the product mixture resulting from a partloular reaction and although It is well establlished that cls- and trans- $\left[\mathrm{Co}(\mathrm{CN})_{2}\right.$ (NCS)Cl] Cl erystallize from the product mixture, the possiblilty of the exlstence of slda products could not be ruled out. It was nocessary, therefore, to obtain positive identiflcation of the fractions eluted frow the colum. For this purpose it has been convenlent to rely heavily on infrared spectroscopy.

Fractions eluted from the lon-exchange column were allowed to evaporate at room temperature untll crystals were obtalned. Crystals 
Isolated In this manner were then mounted in potass lum bromide pellets for Infrared studies. Fortunately, a large quantlty of work had been done on the Infrared spectra of coordlnation compounds, and a major portion of that on compounds Identlcal and closely related to those obtalned here.

In 1954, Faust and quagllano ${ }^{18}$ reported the results of thelr study of the infrared and ultraviolet spectra of cls- and trans$\left[\mathrm{Co}\left(\mathrm{NH}_{3}\right)_{4}\left(\mathrm{NO}_{2}\right)_{2}\right] \mathrm{Cl}$ in the solld state. They adapted to coordination compounds the then new and conventent potass lum bromlde disc method of preparing solld organle samples for infrared spectral study developed In 1952 by stimsen and o'Donnel1. ${ }^{19}$ Analys ls of these spectra showed fower absorptlon peaks in the spectrum of the trans compound than in that of the cls compound. This result was attributed to the operatlon of a netural selection rule, according to whloh the less symetrleat molecule will exhlbit more Infrared-active vibratlonal modes than the more symmetrleal molecule.

A generally appllcable method had, at thls tlme, not been devoloped for dlstingulshing geometrlcal Isomers of coordination compounds, and It was not long before the posstbllity of utlitzing differences in the Intrared spectra as erttorton was explored. Merritt and Wiberly, ${ }^{20}$ in 1955, sfudled the spectra of number of bls lethyleneal aml hel cabalt(III) complexes and concluded that the peak in the six micron reglon was alway displeced toward a lower frequency in the spectrum of the trans isomer.

In on effort to elueldate the nature of the bonding in thlocyanato IIgands, Chamberlain and Ballar, ${ }^{21}$ In 1959, Investlgated 
the Infrared spectra of number of ethylenedianthe and amil ne cobalt(III) complaxes contalning coordinated thlocyanate. They were able to make several frequency ass Ignments to $\mathrm{NH}$ vibratlons by deuterating the ammine and ethylened amine nitrogens. They also concluded that the reglon between 1120 and $1150 \mathrm{~cm}^{-1}$ could be used to differentlate between eis and trans isomers in compounds of this type where the spectra of the cls compound showed two peaks and that of the trans compound only one.

In 1960 Morrls and Busen ${ }^{22}$ tudied the Infrared spectro of deuterated and undeuterated is and trans isomers of $\left[\mathrm{Co}(\mathrm{en})_{2}\left(\mathrm{NO}_{2}\right)_{2}\right]^{+}$ and $\left[\mathrm{Co}(e n)_{2} \mathrm{Cl}_{2}\right]^{+}$. They osslgned the $3200 \mathrm{~cm}^{-1}$ peak to the $\mathrm{NH}_{2}$ streteh, the $1600 \mathrm{em}^{-1}$ peak to the assymetrle deformatlon, the 1350 $\mathrm{cm}^{-1}$ peak to the symmetrle deformatlon, and the $800 \mathrm{~cm}^{-1}$ peak to the $\mathrm{NH}_{2}$ rock. In addition, they observed the appearance of two peaks in the spectrum the els lsemer and only one in that of the trans in the $1600 \mathrm{em}^{-1}$ reglon.

In hls Investigation of differences in the spectro of els and trans arrangements es athylenedlanine chelate rings, M. E. Baldwin, ${ }^{23}$ In 1960, ralsed objectlons to the criterla proposod by Chamberlain and Ballar and suggested Instead that the reglon 870-900 en. ${ }^{-1}$, ass lgned to the $\mathrm{CH}_{2}$ rock, be amployed to distingulsh botween isomers. In this reglon he observed conslstent splltting of the absorptlon peak Into fwo posks In the opectro of the cls compounds. No such splltting occurred In the spectro of trans complexes. Since the trls(ethylened amine) cobalt (III) lon also exhlbited the splltting, the assumed it to the to the proximlty of two athylenediamine chelate rIngs. Howevar, Rlggs and Sherwln, 24 In 1965, observed slmilar 
splitting to occur in dianine-ethylenodlanine complexes and, therefore, concluded that the ffect of Interaction of els $\mathrm{NH}_{2}$ groups on the $\mathrm{CH}_{2}$ vibration was responsible for the splltting. They also denonstrated that differences in symetry were not responsible for the different number of peaks.

IV. The Reaction

The raction which has been studied is a lmple IIgand exchange reaction where the stronger thlocyanato IIgand has replaced a chloro IIgend In coordination to tripositlve cobalt. The octahodral transdichlorobls(ethylenedlanine) cobalt(III) chlorldo and potasslum or sodlum thlocyanate mixed in equimolar portlons In solution and heated. Werner, who first carrled out the reaction in 1912, Isolated cls- and trang- $[\operatorname{colen})_{2}$ (NCs)Cl]cl from the cooled mixtura. The cis compound erystallized rapldly, whlle the much moro soluble trans isomer preelpltated with further evaporation.

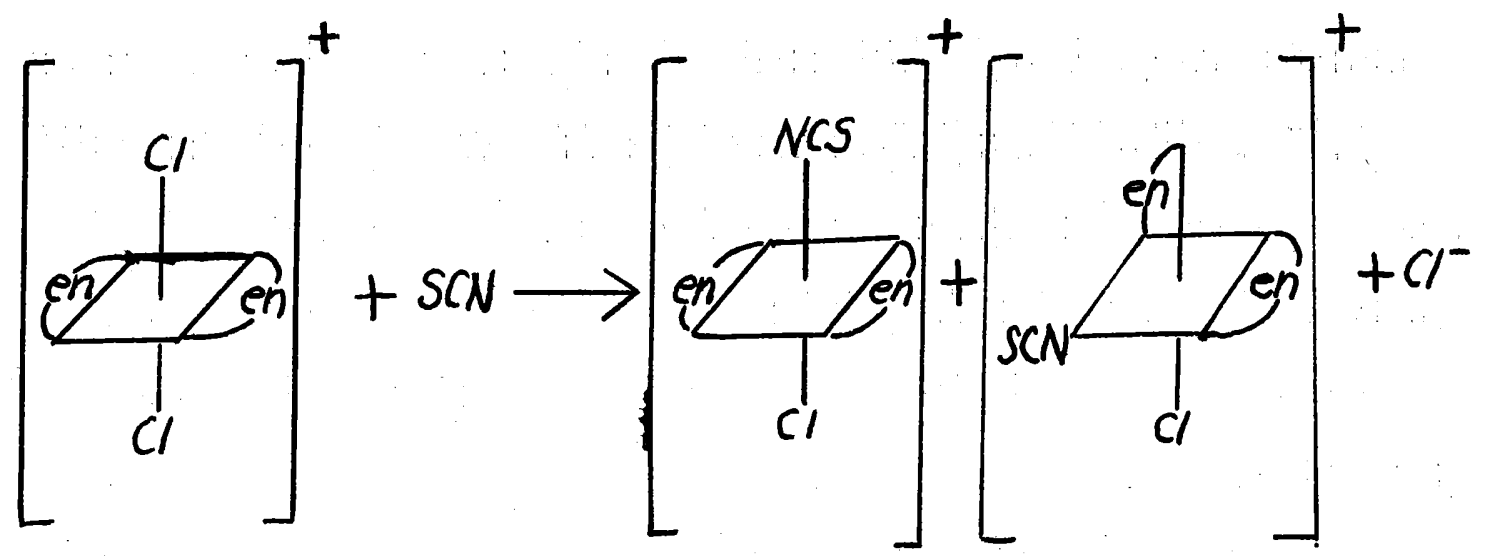


The cis isomer has been resolved into its optically active components and has been shown to aquate, rapidly with heating, in aqueous solution. 25 


\section{EXPERIMENTAL}

I. Introduction to the Experimental Work

As stated prevlously, the basle plan of the research was to run the reaction and then separate the products by lon-exchange chromatography. The products thus separated would then be Identlfled by some means. It was expocted that els-and trans- $\left[\mathrm{Co}(e n)_{2}(\mathrm{NCS}) \mathrm{Cl}\right] \mathrm{Cl}$ would be isolated In thls manner, but thase compounds are not excluslve posslbllitles. It is not unreasonable to presume that both chloro groups might be roplaced by thlocyanate on a slgnlfleant traction of the complex lons leaving soma of the reactant untouched, In whlch case both the dichloro compounds and the dithlocyanato conpounds would also be present In the reaction mixture. Theretore, a Ilst of poss lbllltles would Inelude the following:

$$
\begin{aligned}
& \text { cls- } \left.[\mathrm{Colen})_{2} \mathrm{Cl}_{2}\right]^{+} \text {(I) isomerization of the reactant takes place) } \\
& \text { trans- } \left.[\mathrm{Colen})_{2} \mathrm{Cl}\right]^{+} \\
& \text {cls- }\left[\mathrm{Co}(\mathrm{an})_{2}(\mathrm{NCS}) \mathrm{Cl}\right]^{+} \\
& \text {trans- } \left.\left[\operatorname{col}(a n)_{2}(\operatorname{trcs}) c\right)\right]^{+} \\
& \mathrm{cls}-\left[\operatorname{Co}(\mathrm{en})_{2}{ }^{(\mathrm{NCS})}\right]^{+} \\
& \left.\operatorname{trans}-[\operatorname{Colen})_{2}^{(N C S)} 2\right]^{+}
\end{aligned}
$$

In addition, mono and diaquated produets of ony of the above cannot be exeluded. The most Ilkely Ilgands to be replaced by water, however, are the chloro groups. Ethylenedianine is very strong chelating agent, and the thloeyanato Ilgand has been roported to be highty resistant to aquation even in bolling water. 26 Both cls-and trans$\left[\mathrm{Co}(\mathrm{en}) \mathrm{Cl}_{2}\right]^{+}$are known to aquato readlly to $\mathrm{els}-\left[\mathrm{Co}(\mathrm{en})_{2}\left(\mathrm{H}_{2} \mathrm{O}{ }_{2}\right]^{+1+}, 27\right.$ 
and $\mathrm{cls}-\left[\mathrm{Co}(\mathrm{en})_{2} \text { (NCS)C1 }\right]^{+}$has been shown to aquate, particularly at elevated temperatures, to $\mathrm{cls}-\left[\mathrm{Co}(\mathrm{en})_{2}(\mathrm{NCS})\left(\mathrm{H}_{2} \mathrm{O}\right)_{2}\right]+$. The trans isomer also aquates but at a much lower rate than the els form and appreciably only at temperatures above 50 degrees. ${ }^{28}$ The latter compounds (espectally cis- $\left[\mathrm{Co}(\mathrm{en})_{2}(\mathrm{NCS})\left(\mathrm{H}_{2} \mathrm{O}\right)_{2}\right]^{++}$) might be considered probable components of the product mixture since cls- and trans-

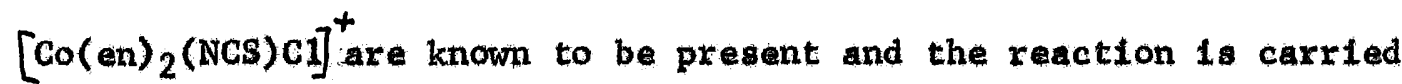
out in aqueous solution and requires heat. Fortunately infrared spectra can distingulsh all of the above-named compounds.

II. Preparation of the Starting Compound

Trans- $\left[\mathrm{Co}(\mathrm{en})_{2} \mathrm{Cl}_{2}\right] \mathrm{Cl}$ was prepared by the mathod of BaIlar. 29

Six hundred grams of 10 per cent solution of ethylenediamine is added, with atirring, to a colution of $160 \mathrm{~g}$. of cobalt chloride 6-hydrate in $500 \mathrm{ml}$. of watex in a 21 . beaker or bottle. A vigorous stream of air is drawn or passed through the solution for 10 or 12 hours. (Longer aeration causes undesirable secondary reactions to take place.) Three hundred and fifty millilters of concentrated hydrochloric acld is added, and the solution is evaporated on a steam bath until a crust forms over the surfice $(750 \mathrm{ml}$.). The solution is allowed to cool and stand overnight before the bright-green square plates of the hydrochlortde of the trang- form are filtergd. These are washed with alcohol and ether and dried at $110^{\circ}$. At this temperature, the hydrogen chloride is lost, and the crystals crumble to a dull-green powder. Yleld $83 \mathrm{~g}$. ( 52 per cent based on the ethylenediamine).

These directiona were followed closaly. However, after filterIng the crystals, the filtrate was evaporated further unt1 it crusted over again, whereupon a second batch of crystals was obtained. This process was repeated successfully a third time but the crystals obtained on a fourth attempt were contaminated with light-yellow- 
green needle-shaped crystals. Using half amounts of those given in the above instructions, a total yield of $58 \mathrm{grams}$ or 72.6 per cent Wras obtained.

The compound was analyzed for cobalt by an electrodeposition method, ${ }^{30}$ The per cent cobalt calculated for $\left[\mathrm{Co}\left(\mathrm{C}_{2} \mathrm{~N}_{2} \mathrm{H}_{8}\right) \mathrm{Cl}_{2}\right] \mathrm{Cl}$ is 20.6, and the per cent found was 20.5. (see page 47).

III. The Reaction between trans- $\left[\mathrm{Co}(e n)_{2} \mathrm{Cl}_{2}\right] \mathrm{C1}$ and SCN. 8

In a typical reaction, $20 \mathrm{~g} \cdot(.072 \mathrm{~mole})$ of trans$\left[\mathrm{Co}(\mathrm{en})_{2} \mathrm{Cl}_{2}\right] \mathrm{Cl}$ was dissolved in $30 \mathrm{ml}$. of water. Moderate heating was necessary to achieve complete solution. Immediately upon addition of a solution of $6.8 \mathrm{~g} .(.070 \mathrm{~mole})$ of $\mathrm{kSCN}$ in $15 \mathrm{ml}$, of water, fine green crysta1s of trensm $\left[\mathrm{Co}(\mathrm{en})_{2} \mathrm{Cl}_{2}\right] \mathrm{sGN}$ formed profusely. The resulting bright-green slurry was heated with constant atirring unt 11 complete solution of the green solid was obtained at about 85 degrees. The solution was then allowed to cool. A large quantity of purple exystals of ela-[Co(en) ${ }_{2}$ (NCS)C1] Cl precipitated within an houx. The crystals were filtered on a Buchner funnel, washed with 95 per cent ethano1, and dried in air. The deep-violet filtrate yielded more of the purple crystals upon further standing. In one particular instance where the solution was allowed to stand overnight before any cryatals were filtered, approximately $18 \mathrm{~g}$. of the compound was obtained. The purity was not, however, determined.

IV. Ion-exchange Separation.

A number of Ion-exchange separations of the product mixture 
resulting from the above reaction were carried out. The earliest ones were of an exploratory nature, the objective being to see how many bands formed, what they looked like, to what extent they could be separated, and what kind and strength of eluting solvent should be used to perform an optimum separation. Some later column separations were carried out to isolate material for Identification purposes. Finally, three separations were performed for the sole purpose of estimating the relative proportion in which the products were formed. It is useful to describe only one typlcal separation here. Any variations observed will then be discussed.

Most of the colunn separations were carrled out in $50 \mathrm{ml}$. glass burets. A glass wool plug was inserted above the stopcock to retain the resin. The resin (Dowex $50 \mathrm{~W}-\mathrm{X} 4$ and $50 \mathrm{~W}-\mathrm{X8}$ were used) was washed with the oolvent to be used initially for luting, and then poured in a slurry Into the column. More solvent was introduced through the top of the column and allowed to run through the resin, the solvent level never being allowed to fall below the top of the column of resin. When the resin had settled wel1, a second glass wool plug was inserted at the top of the resin column to prevent its disruption when introducing the solution to be analyzed, and to filter out insoluble matter such as dust. The solvent was then allowed to flow to the level of the uppar glass wool plug and a portion of the solution to be analyzed was poured into the column. When the solution had fallen to the level of the upper glass wool plug, eluting solvent was again introduced and thereafter maintained at a constant level approximately $25 \mathrm{ml}$. above the resin colum. Eluent was introduced through rubber tubing from a 
flask placed above the level of the top of the buret, The flow-rate was adjusted by means of a screw clamp to Increase very gradually and a constant head was maintained at the desired level by drawing the excess off with an aspirator.

\section{A. A Continuous Elution}

In a particular run $1 \mathrm{ml}$. of product mixture, from whlch no crystals had yet formed, was pipetted onto column packed with Dowex 50W-X8 resin to height of $29 \mathrm{~cm}$. Elution was begun with $0.5 \mathrm{M}$ HCL, a constant head being maintained at $23 \mathrm{ml}$. above the resin. The flow rate was approximately $0.7 \mathrm{ml}$. per minute. Early in the elution three colored bands began to form; a broad dark-violet lower band (非), a somewhat smaller reddish band a short distance behind (\$2), and a very narrow red band at the top of the column ( $1 / 3)$. As elution progressed, separation improved, and bands 1 and 1 moved gradual1y down the column, 非 moving most rapld1y. Eventual1y, 非 separated Into a slowmoving 11ght-red-colored band (作b), and a mobile reddish band (非a). When band $\mid 11$ had eluted, the strength of the eluent was increased to 1 M. The solvent collected between bands $\# 1$ and $\$ 2$ a was colorless, Indicating that a complete separation of these fractions had been accomp 1ished, and that no aquation had occurred in band $\|_{1} 1$. Band $\# 2 b$ became more diffuse, and the area between band $k_{2} \mathrm{a}$ and band $\mathbb{k}_{3}$ (which had begun to move slowly after the change in eluent strength) was 1ightly pink-colored rather than the off-white color of the resin. After band $\# 2$ was collected the acld strength was increased to $3 \mathrm{M}$,

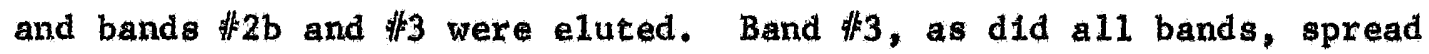


out somewhat as it moved down the column. A 1 ight pink band remained at the top of the column which could not be collected since it spread and became very diffuse with further elution.

A record of the above separation was kept and is reproduced here. It was run without cessation, requiring a total of 31.5 hours to complete.

RECORD OF ELUTION

Time Elapsed

0

2 hrs. 35 min.

5 hrs, 50 min.

12 hrs, 20 min.

14 hrs. $40 \mathrm{~min}$.

15 hrs.

$19 \mathrm{hrs}, 25 \mathrm{~min}$.

25 hrs.

31 hrs. $30 \mathrm{~min}$.

\section{Comments}

Elution is begun with $0.5 \mathrm{M} \mathrm{HCL}$.

Bands 非, 2 , and $k^{3} 3$ have clear $1 \mathrm{y}$ separated. $\$ 3$ looks quite small at this point.

非 1 is wel1 separated from $\$ 2$ which has split into a strong lower and a weak upper band.

The region between $k_{2}$ and $\|_{3}$ is light pink instead of the off white of the resin, indicating incomplete separation.

Band 1 ia completely eluted.

Eluent is changed to $1 \mathrm{M}$ HCL diffuse.

\#2a has eluted. \#2b is very faint,

Eluent is changed to $3 \mathrm{M}$ HCI.

\#3 has eluted. Shut off.

\section{B. Interrupted Elutions.}

The above separation was run without atopping the flow of eluent through the column at any time, but most of those carried out were 
(due to the length of time necessary to complete a separation) shut off a number of times when they couldn't be checked within an hour. In columns which were eluted over a greater length of time, with frequent interruption, it was observed that two or three more bands formed between the $\# 2 b$ and $\# 3$ bands on the column at the expense of band $\# 2 a$. Since these bands appeared to spl1t off from band $2 a$, they were labeled 非2b, 非 $2 \mathrm{c}$, and 非 $2 \mathrm{~d}$, three being the most observed, and usually just two. In one of the last separations made, the $\left.\right|_{2} 2 \mathrm{~d}$ band was much stronger than band $k^{2 a}$ by the time $k_{2 a}$ eluted. It eventually became clear that the new bands were appearing when elution was resumed following an interruption, indicating that something had happened to the materia 1 in band $\left.\right|_{2}$ during a stationary period. The bands formed in this manner appeared to elute at about the same rate and with the same strength acid as band 3 . In all of the separations it was noted that the region between bands $\#^{2} \mathrm{a}$ and pink color.

\section{Other Comments on Elutions}

In some of the column elutions which were performed it was observed thatalight violet band separated from the rest of the solution and eluted within one half hour of commenement of elution. A sufficient amount of thls fraction to obtain crystals was never collected, but it is highly probable that it was a neutral but polar compound.

In addition to the light pink band which remained at the top of the column after elution of band $\$ 3$, some very dark brown material was 
absorbed on the top of the column, and could be moved a 1ittle only with 6 M or stronger HC: 1 .

Other solutions were tried as eluents but none was found to be as satisfactory as HCL. Sodium chloride was found to be too strongly favored by the resin as opposed to the compounds to be separated, as evidenced by the fact the bands spread and ran together when it was used. Sodfun thlocyanate proved to be somewhat better than sodium chlorlde, and was used to advantage in preparing the thiocyanate salts of the complexes for infrared spectra. A problem with using salts as eluting agents was that when the eluted fractlons were evaporated to obtain crystals, crystals from the eluent would precipitate before or coprecipitate with the desired salt. It was thought that perhaps use of a neutral eluent might be preferable to a strongly acidic one but essentially the same results were obtained and the compounds in question appear to be quite stable in strongly acidic media.

V. Isolation of Crystals.

In order to obtain pure exystals for infrared spectral analyais, it was necessary to evaporate the fraction eluted from the fonexchange column. In the first attempts to obtain crystals in this manner, the solutions were evaporated at low heat on a hot plate until they became sufficiently concentrated for crystallization to occur. clear, colorless crystals were obtalned from the firat fraction. It was suspected, and subsequently confirmed by a positive flame test for potassium, that these were crystals of potassium chloride. When the solution was evaporated further, violet crystals coprecipitated with 
the colorless ones.

Evaporation of the second fraction over a hot plate resulted in the formation of small green crystals about the same color as the starting compound, trans- $\left[\mathrm{Co}(\mathrm{en})_{2} \mathrm{Cl}_{2}\right] \mathrm{Cl}$. This was a surprise since the solution from which the crystals precipitated was reddish in color whereas trang- $\left[\mathrm{Co}(\mathrm{en})_{2} \mathrm{Cl}_{2}\right] \mathrm{Cl}$ is green in solution. $\mathrm{C}$ s $-\left[\mathrm{Co}(\mathrm{en})_{2} \mathrm{Cl}_{2}\right] \mathrm{Cl}$, however, is dark violet and it seemed reasonable to hypothesize that the trans form had isomerized to the cis which has been reported to be the more stable form in acid solution. 31

Since it appeared that heating might be causing rearrangements to occur, room temperature evaporations in a fume hood were attempted. Under these conditions, uncontaminated violet crystals were obtained from the first fraction. It is likely, however, that color less crystals of potassium chloride were not isolated, not because of the method of evaporation used, but becauge a different strength eluent was used to elute fraction $\left.\right|_{1}$, achieving a separation from potassium ion. Additionally, a lower acid strength would have a lower chloride ion concentration, requiring moxe evaporation to reach saturation, although, this factor would tend to affeet both $\mathrm{KCl}$ and the violet compound in the same way.

The crystals 1solated from band $\$ 2$ a by slow evaporation at room temperature were significantly different from those obtained by evaporation over a hot plate. After relatively little evaporation had taken place, flaky orange erystals formed on the top of the solution. These were collected on a f1lter. Upon further evapoxation, however, fine reddish crystals were obtained and it appeared that either two 
different compounds were present In fraction $\left.\right|_{2} 2 a$ or one compound was crystallizing in two different forms. No green crystals were obtained in the room temperature evaporations. Slow evaporation of fraction 非 yielded crystals similar to the reddish crystals isolated from 非a. Generally, a sufficient amount of solution was not obtained to 1solate crystals from fractions 非 $2 b$, 非 $c$, and 非 $2 d$.

\section{Infrared Spectra}

The potassium bromide pellet method was used to prepare crystalline samples for Infrared spectra. Spectra were recorded on Perkin-Elmer 137 Infracord and Beckman IR-12 recording spectrophotometers. The IR-12 was the more useful of the two aince it resolved a greater number of absorption peaks and gave more preclse wave number readings. Prectse readings were necessary since the spectra of the compounds to be separated were similar in many respects. Nevertheless, the spectra obtained from the Infracord were of use for comparison purposes, and a number of these spectra are reproduced here. Significant points concerning the analysis of the infrared spectra are noted below.

A. The infrared spectra of the violet crystals from fraction $\|_{1}$ obtained by elution with HC1, and therefore assumed to be the chloride salt (see flgure 1), showed single absorption peaks around $1600 \mathrm{~cm}^{-1}$ and in the $1100-1150 \mathrm{~cm} .^{-1}$, and $870-900 \mathrm{~cm} .^{-1}$ regions, thus indleating that it is of the trans configuration by the criteria of Morris and Busch, ${ }^{32}$ Chamberlain and Bailar, ${ }^{33}$ and Baldwin ${ }^{34}$ respectively. If the compound were of the less symmetrical cis form, two absorption peaks would appear in each of these regions. 
B. Since a single strong thiocyanate $\mathrm{C}-\mathrm{N}$ stretching peak was observed in the $2100 \mathrm{~cm}^{-1}$ region, the trans-dichloro complex was ruled out, leaving as the only two possibilities txans$\left[\mathrm{Co}(\mathrm{en})_{2}(\mathrm{NCS}) \mathrm{Cl}\right] \mathrm{Cl}$, and trang- $\left[\mathrm{Co}(\mathrm{en})_{2}(\mathrm{NCS})_{2}\right] \mathrm{Cl}$. The former was suspected, and subsequently confirmed by comparison of the frequencies of absorption peaks in the spectrum (see figure 2) of crystals isolated by evaporation of band 非 (obtalned by elution with NaSCN, and therefore, assumed to be the thiocyanate salt) with peaks reported by

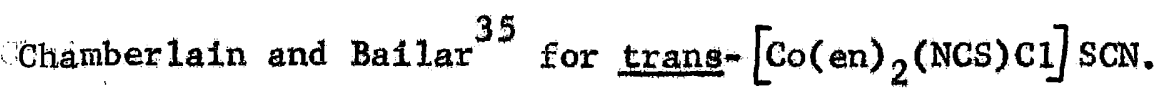

TABLE 1: COMPARISON OF PEAK FREQUENCIES IN THE SPECTRA OF TRANS- $\left[\mathrm{Co}(\mathrm{en})_{2}\right.$ (NCS)C1] SCN AND THE VIOLET CRYSTALS FROM BAND \#1

$\begin{array}{ll}\text { Exans- }\left[\mathrm{Co}(\mathrm{en})_{2} \text { (NCS) C1] sCN }^{-1}\right. & \text { Violet Crystals } \\ 732 \mathrm{~cm}^{-1} & 732 \mathrm{~cm}^{-1} \\ 787 & 787 \\ 1122 & 1127 \\ 2058 & 2060 \\ 2141 & 2140\end{array}$

C. As will be recalled, two types of precipitate were obtained from fraction 非a. Analysis of the Infrared spectrum of the orange crystals (see figure 3) which formed first suggested that the compound was a cls isomer since two peaks appeared in each of the critical regions, around $1600 \mathrm{~cm}^{-1}, 1100-1150 \mathrm{~cm} .^{-1}$, and $870-900 \mathrm{~cm}^{-1}$ of the spectrum recorded on the IR-12. There was one strong thlocyanato peak in the neighborhood of $2100 \mathrm{~cm}^{-1}$, ruling out the dichloro compound. The cis-dithiocyanato compound was ruled out as well since this would cause the appearance of two strong peaks in the 2000-2200 cm."-1 region. Comparison of the spectrum of this compound with that of 


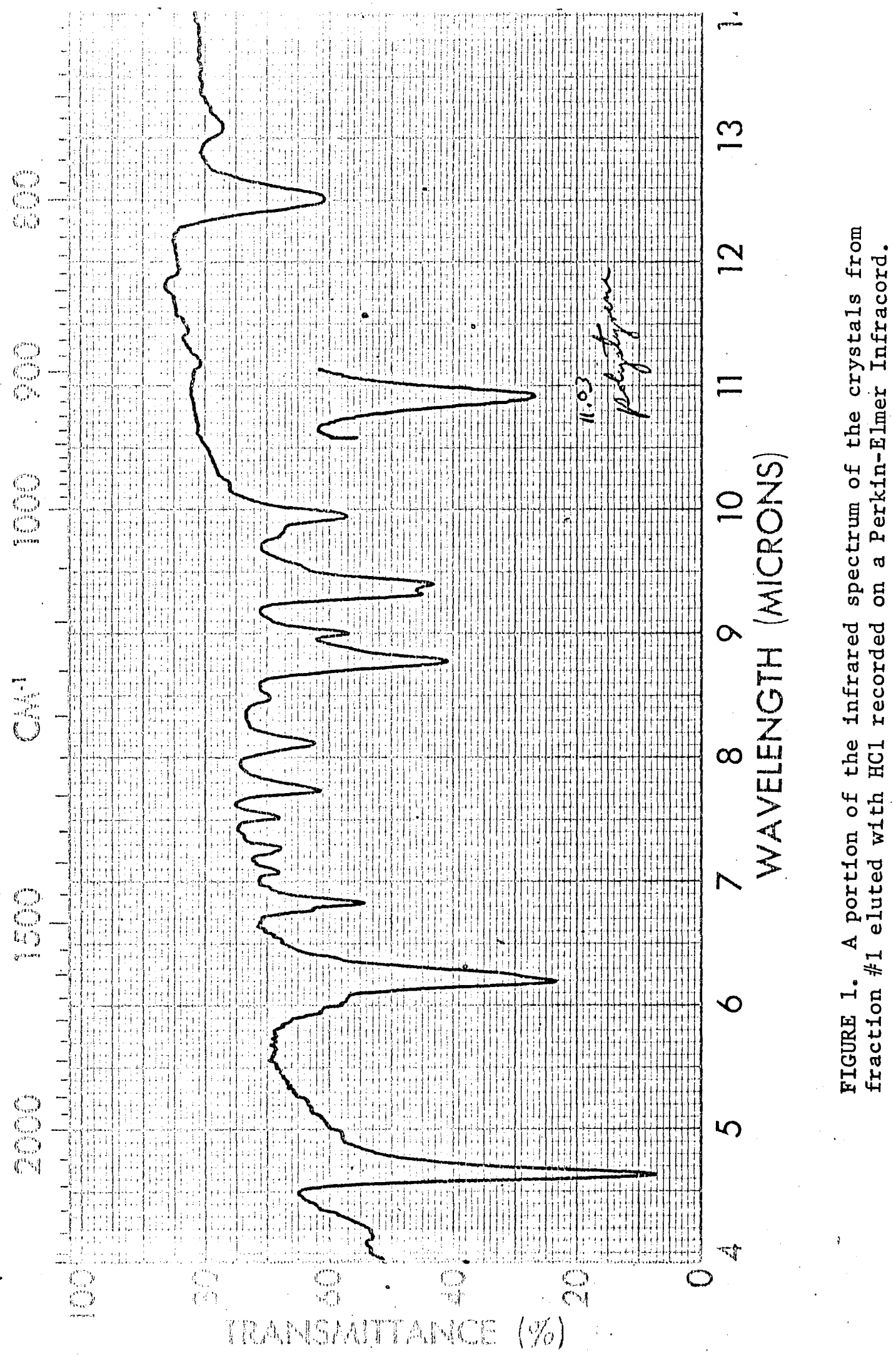




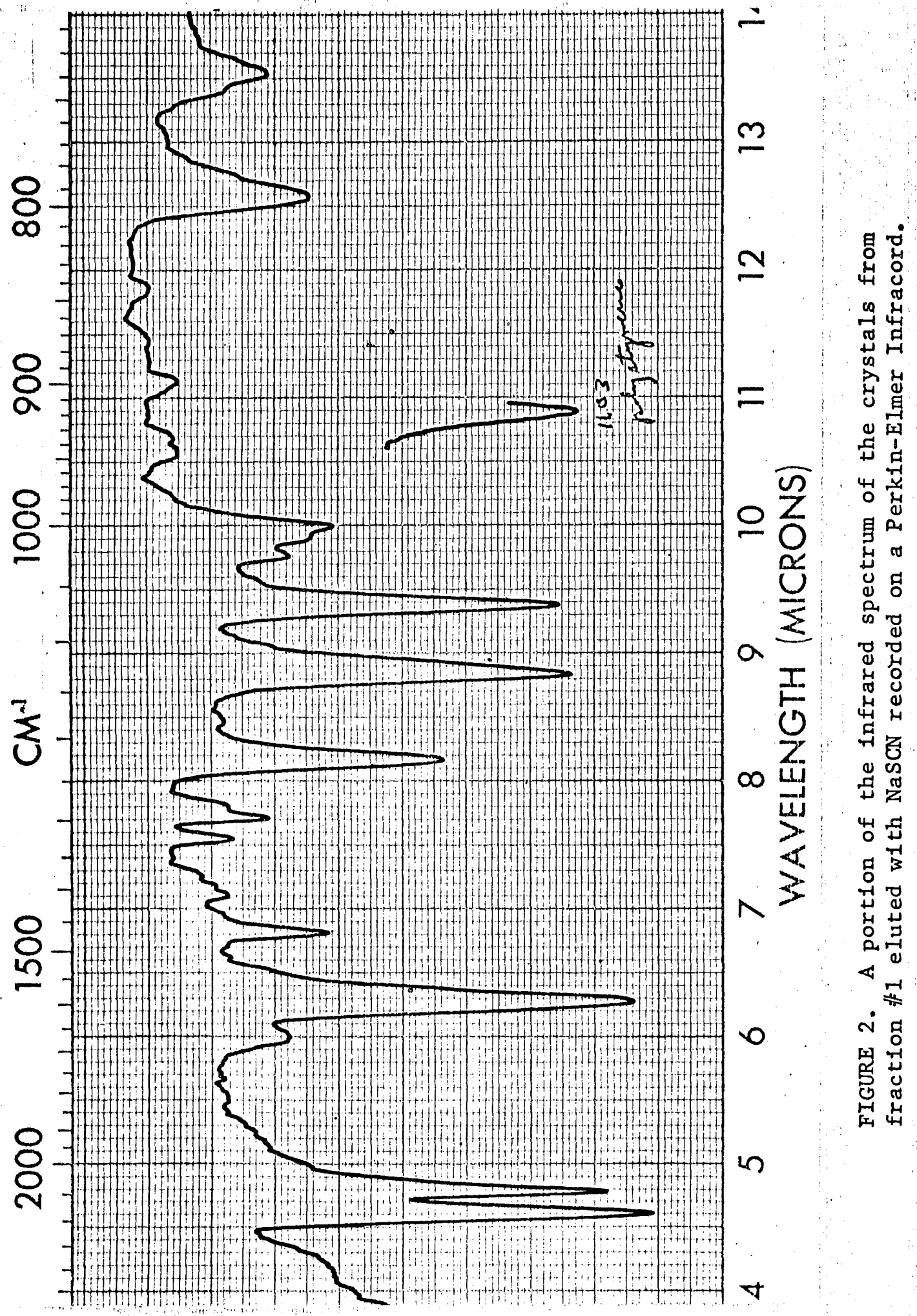




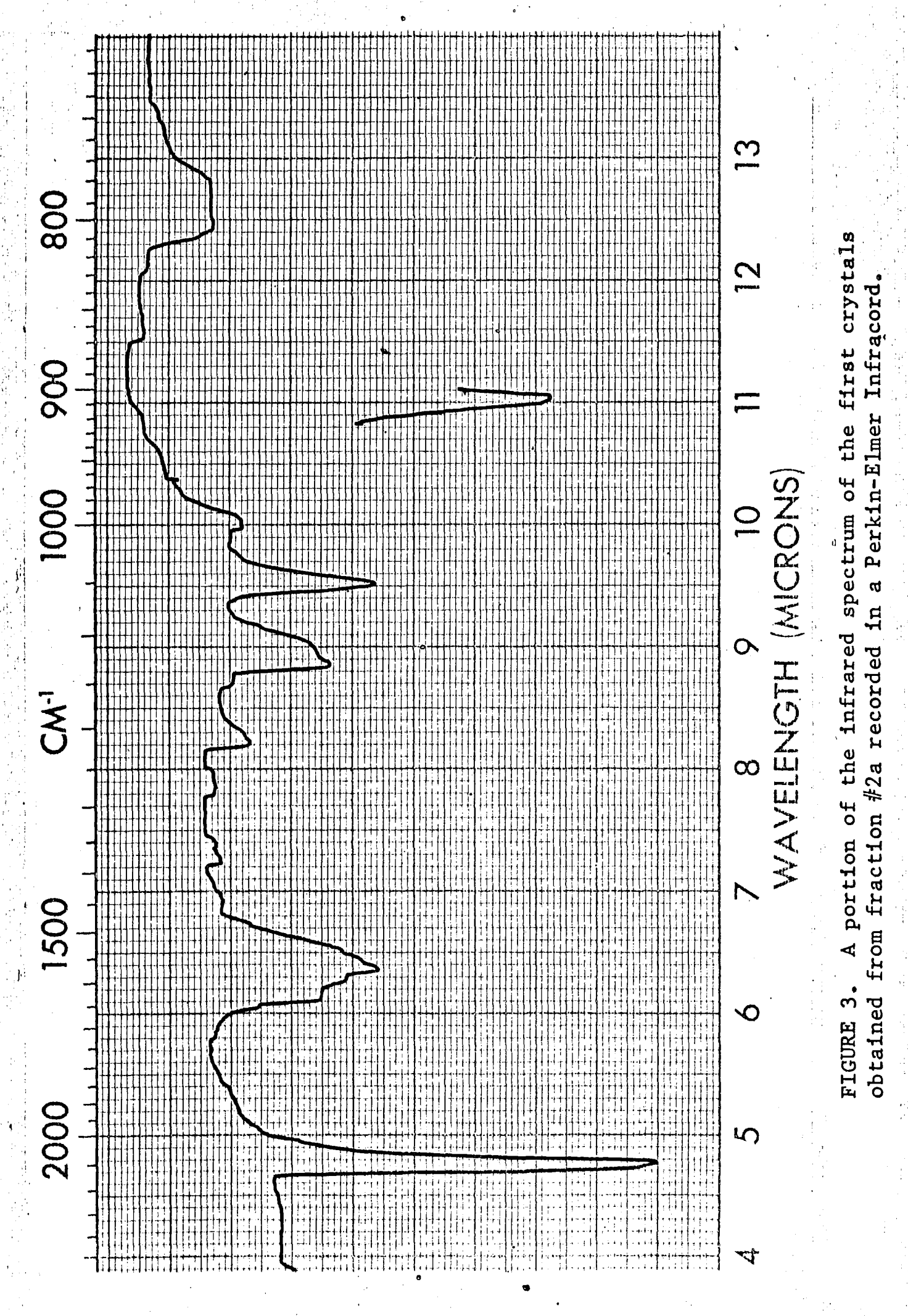




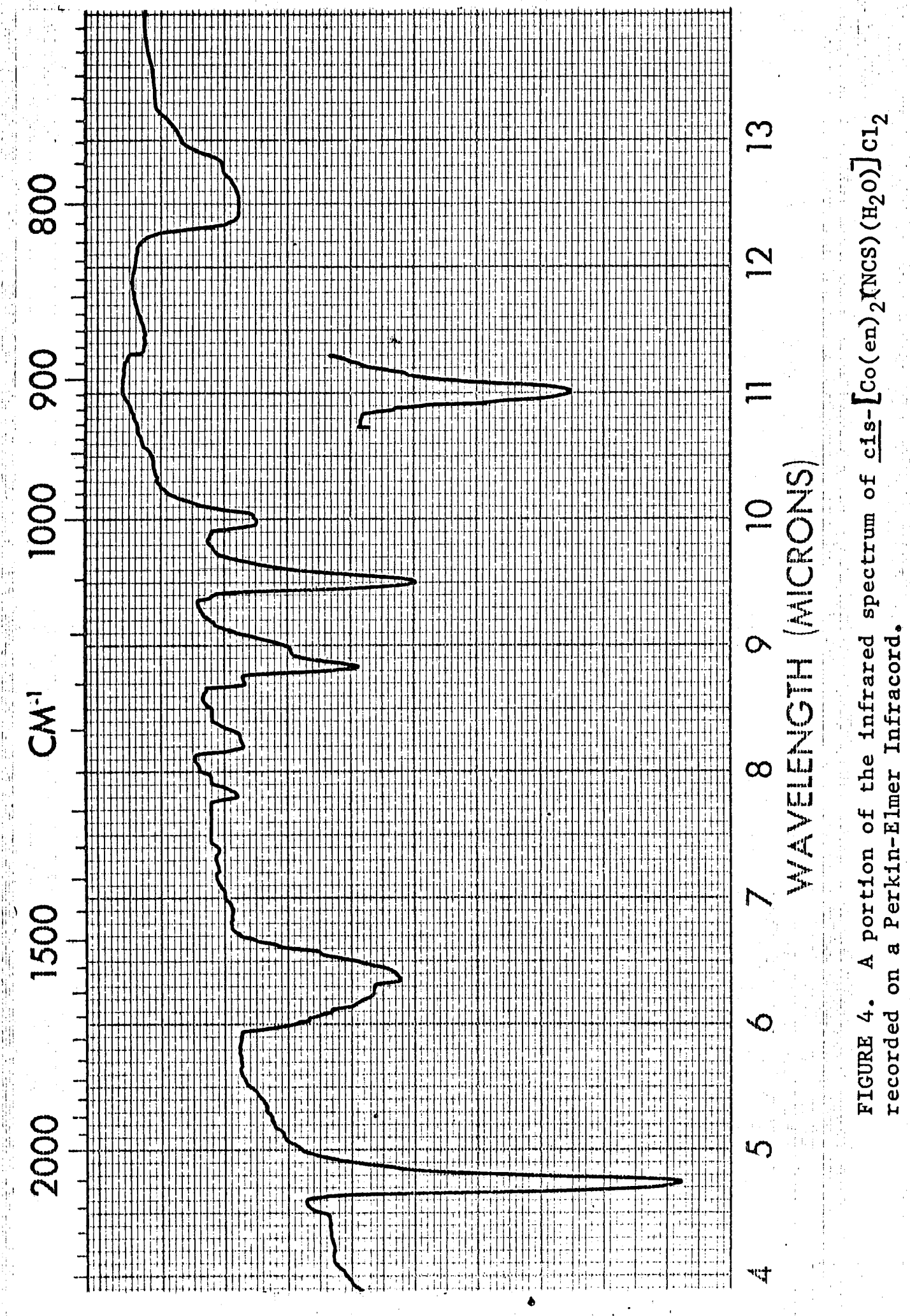




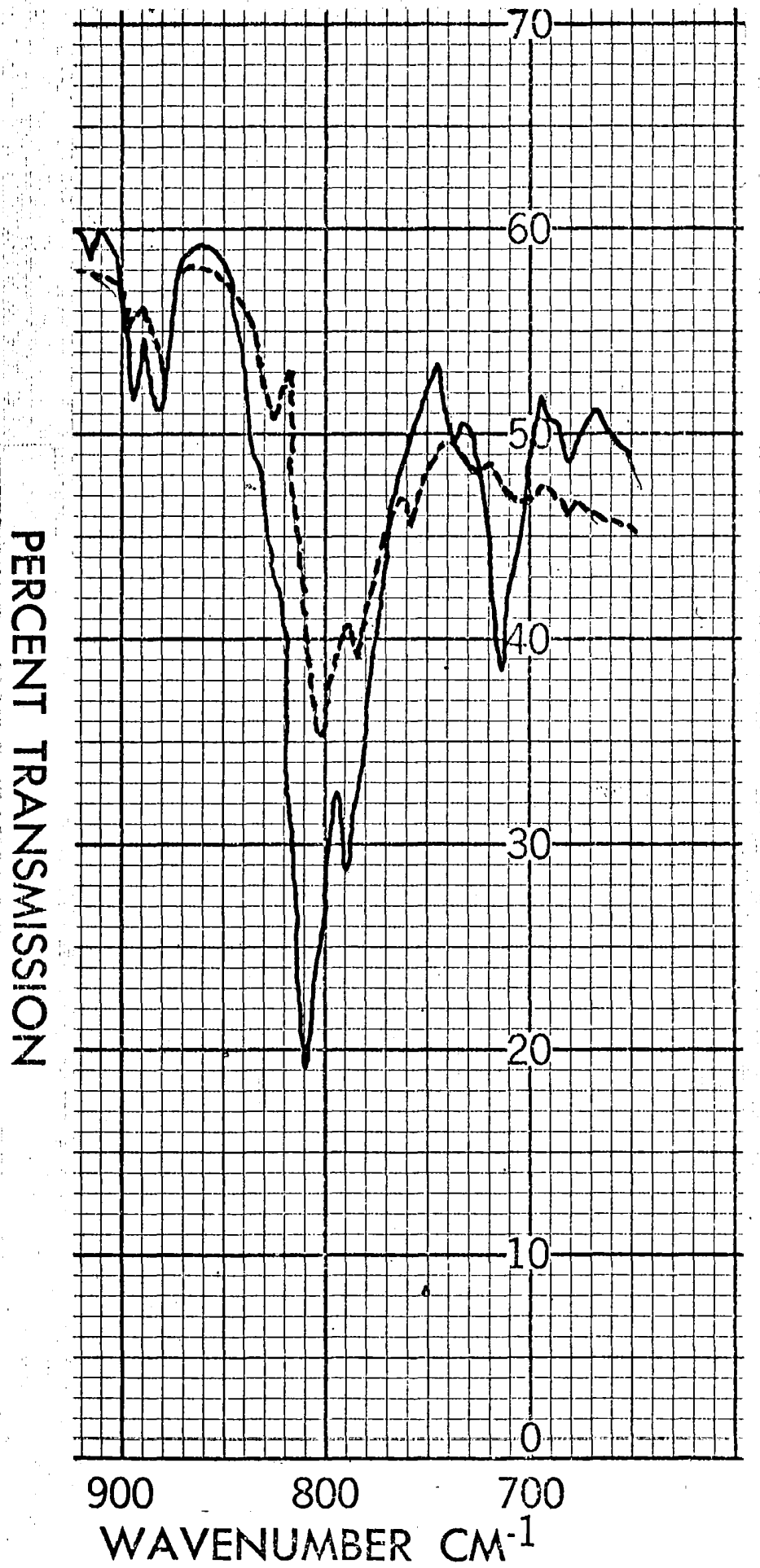

FIGURE 5. The Infrared spectra of c1s-[Co(en) ${ }_{2}$ (NCS) C1] C1 (dashed 11ne) and c1s- $\left.\left[\mathrm{Co}(\mathrm{en})_{2}(\mathrm{NCS}) \overline{\left(\mathrm{H}_{2}\right.}, 0\right)\right] \mathrm{Cl}_{2}$ (solid line) in the neighborhood of $700 \mathrm{~cm}$ - $^{-1}$ recorded on a Beckman IR-12, 


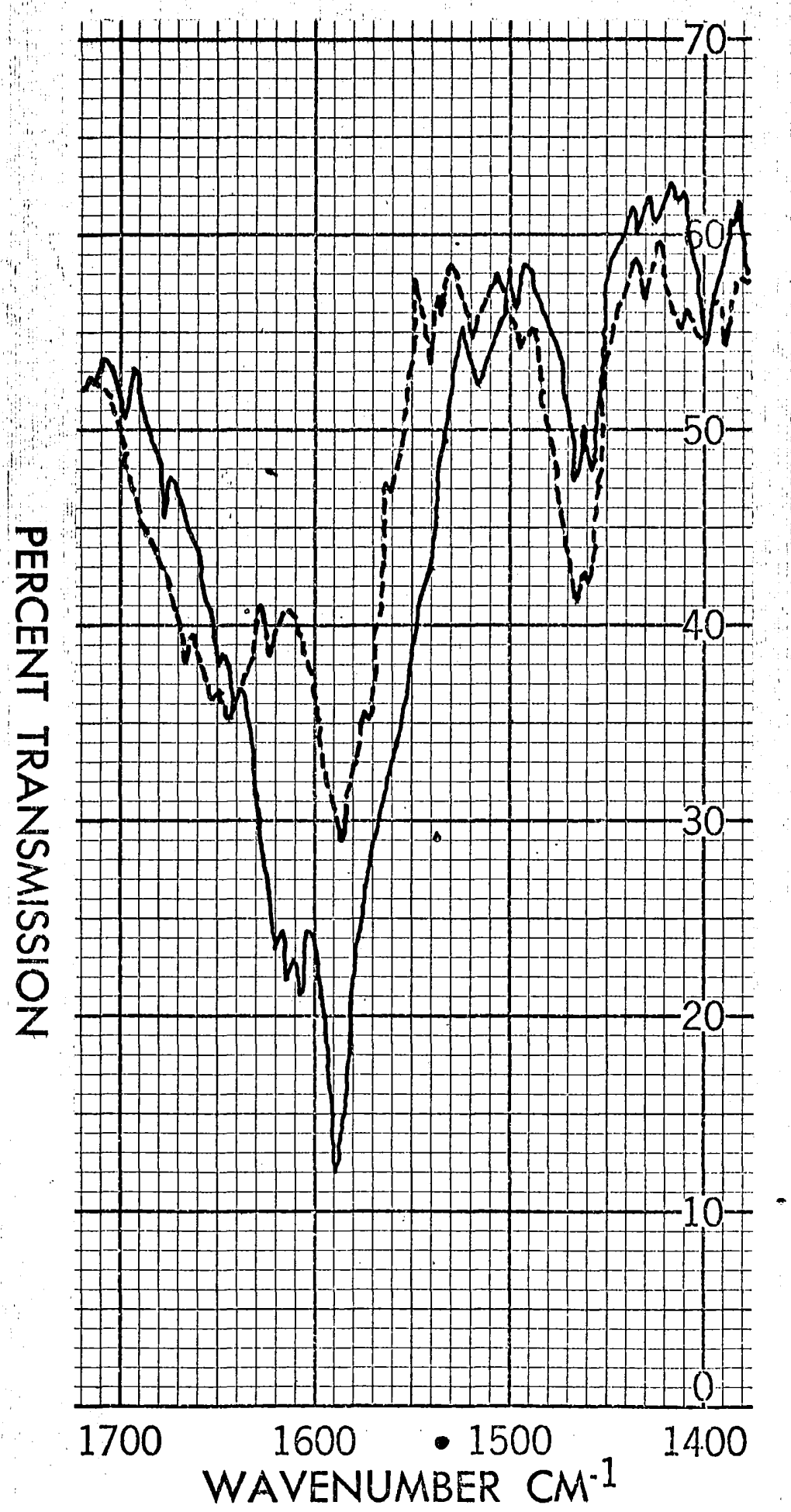

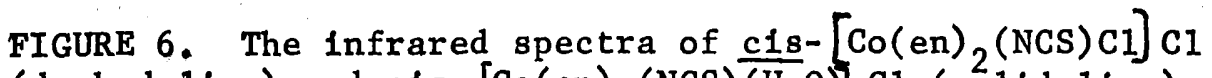
(dashed 11ne) and $\mathrm{cls}-\left[\mathrm{Co}(\mathrm{en})_{2}(\mathrm{NCS})\left(\mathrm{H}_{2} \mathrm{O}\right)\right] \mathrm{Cl}_{2}$ (solid line) in the neighborhood of $700 \mathrm{~cm}^{-1}$ recorded on a Beckman IR-12. 


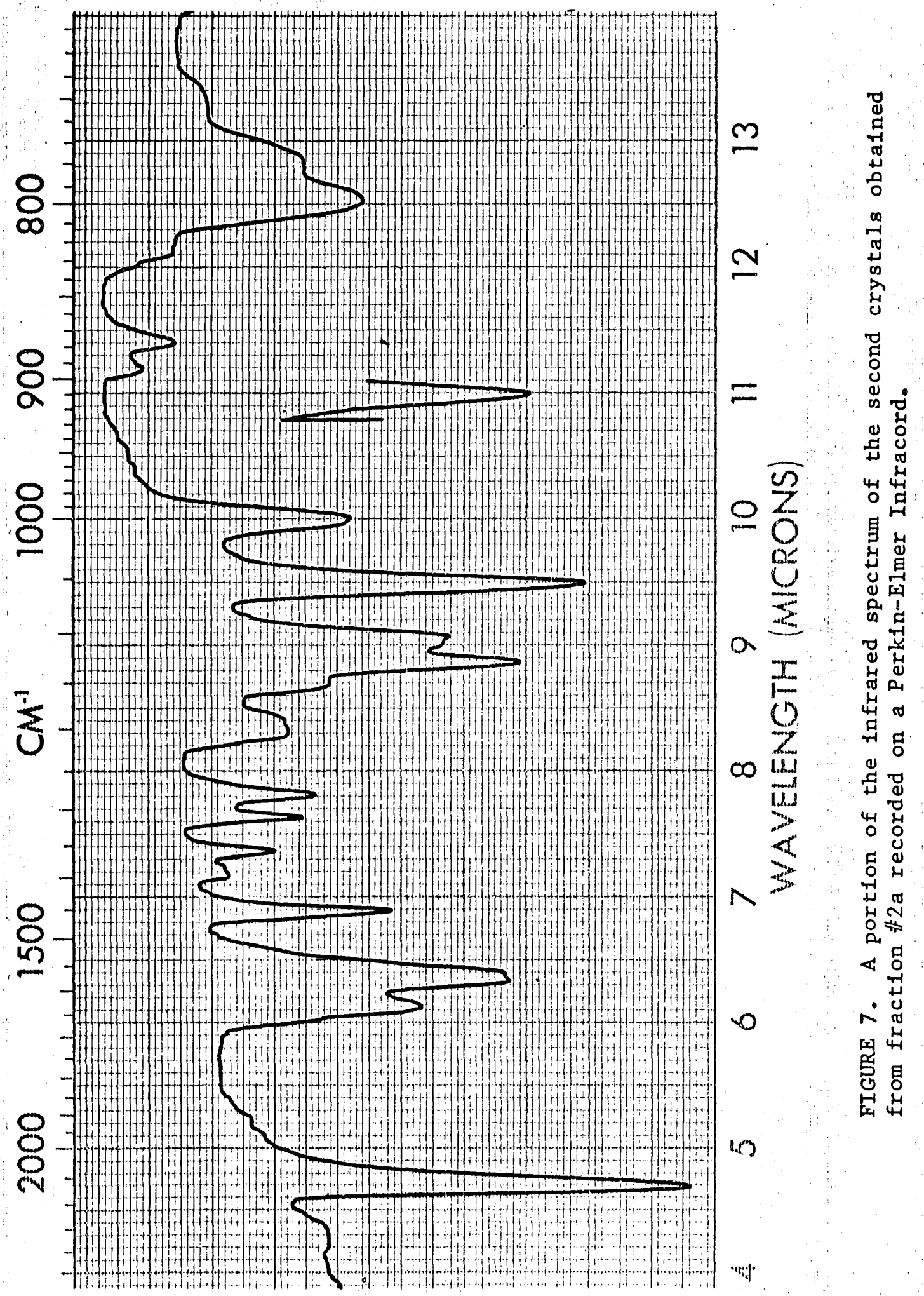




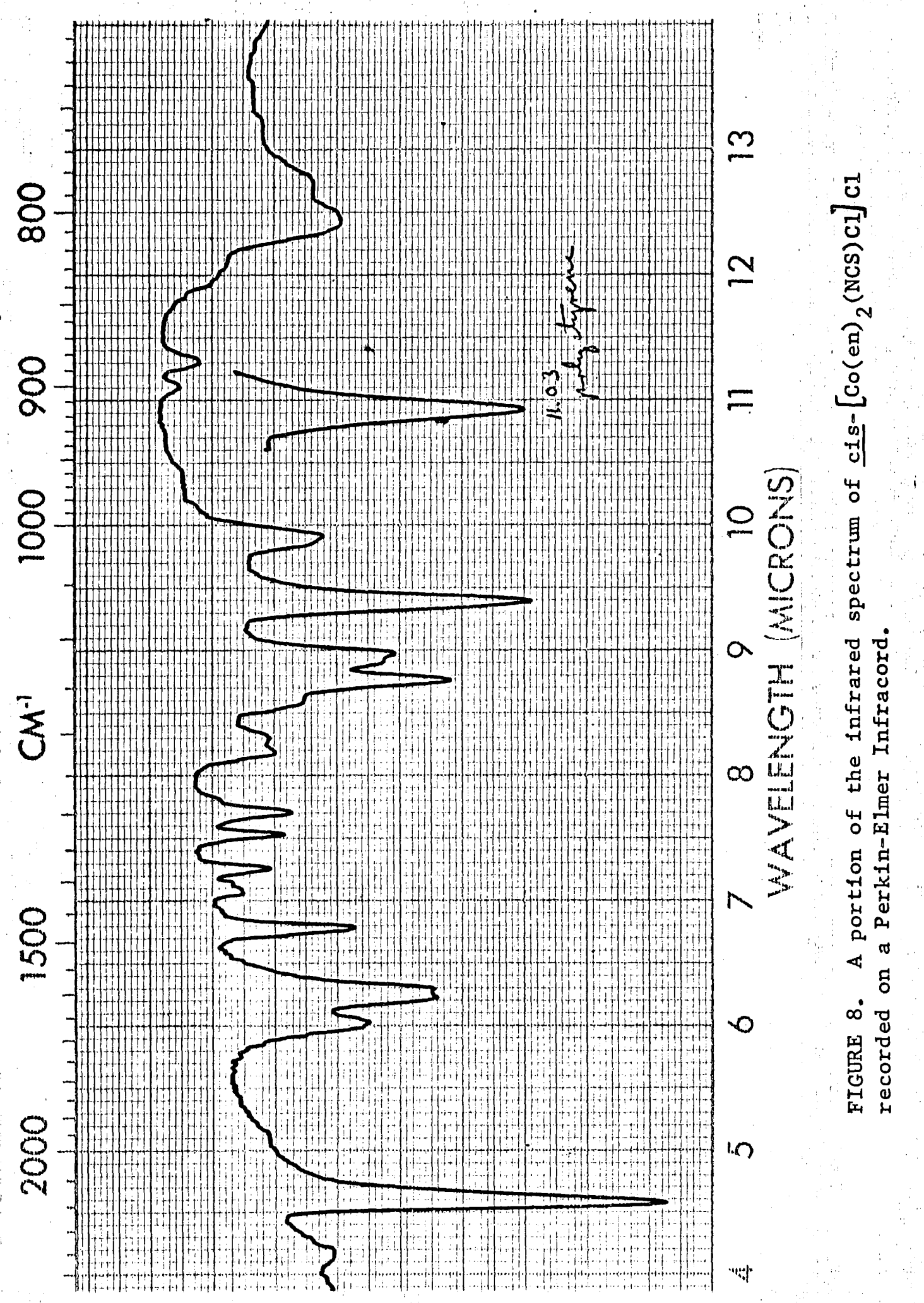




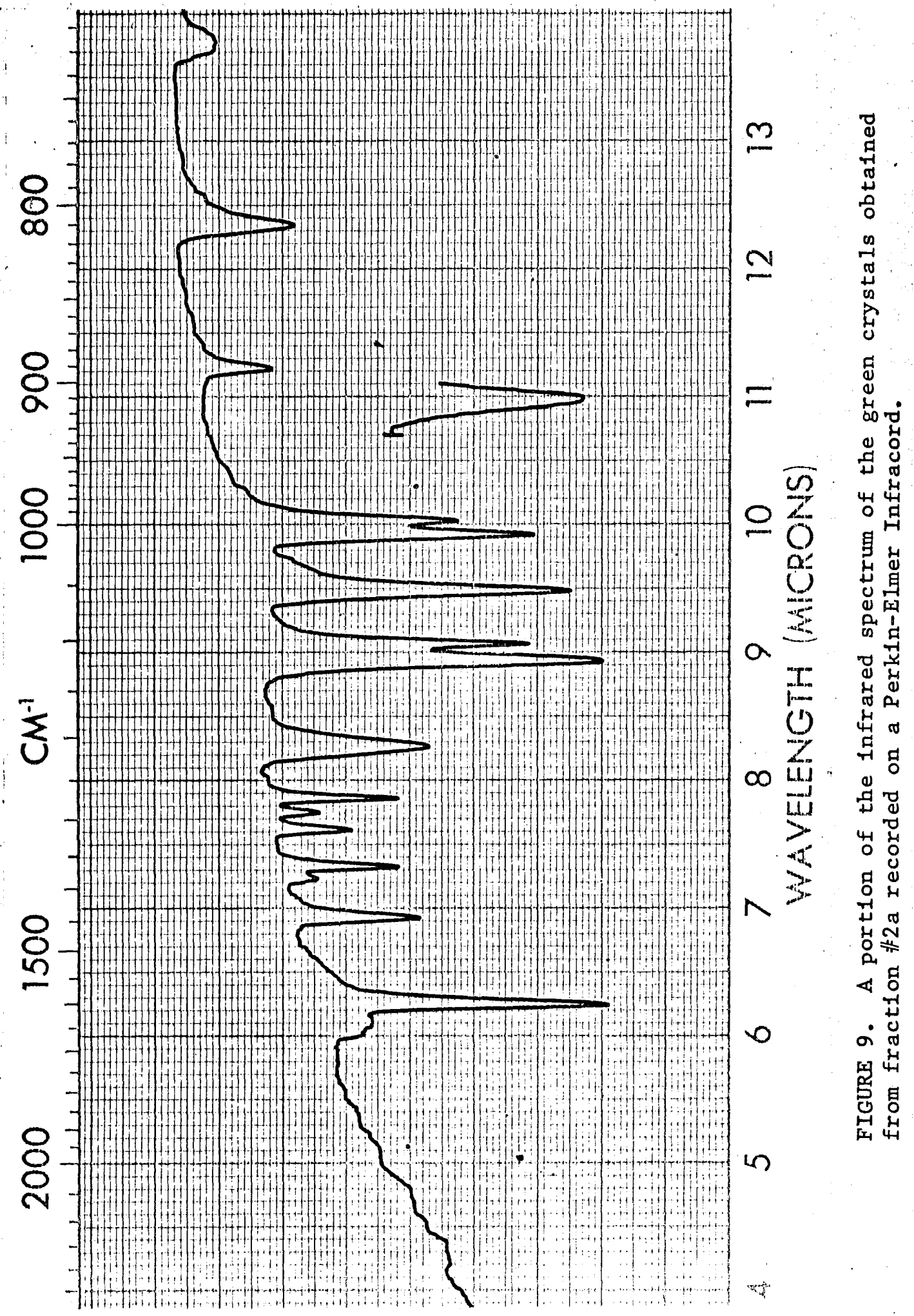




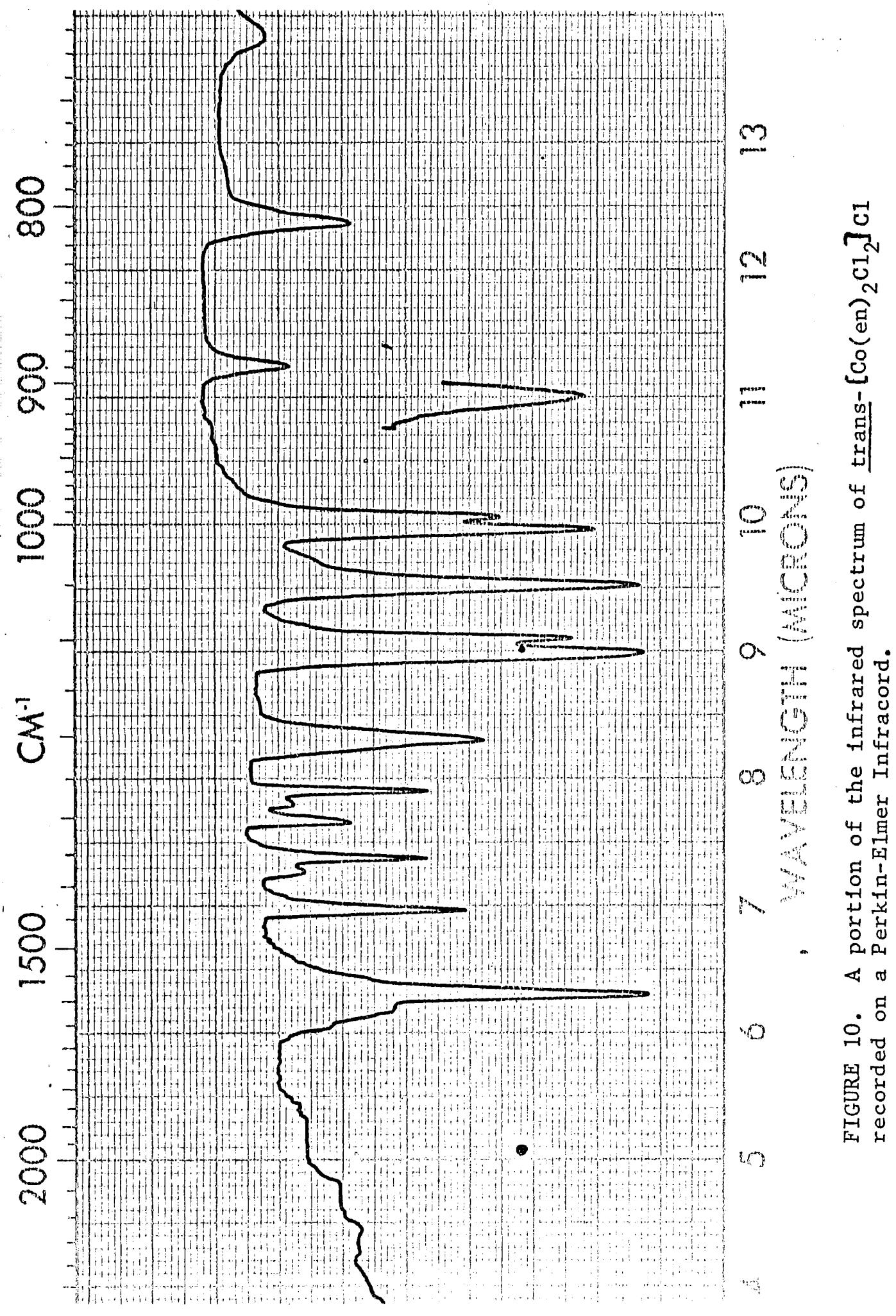




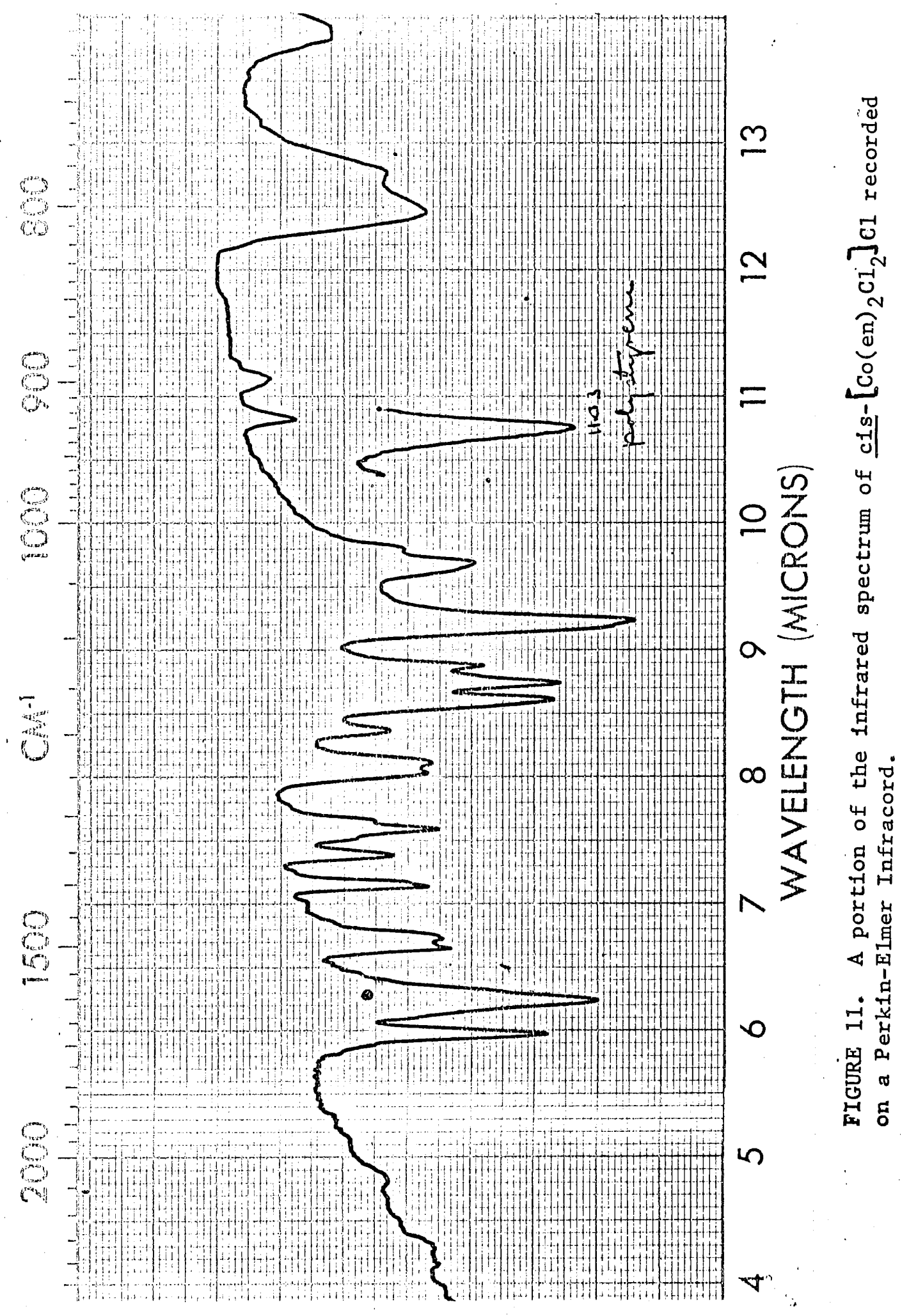




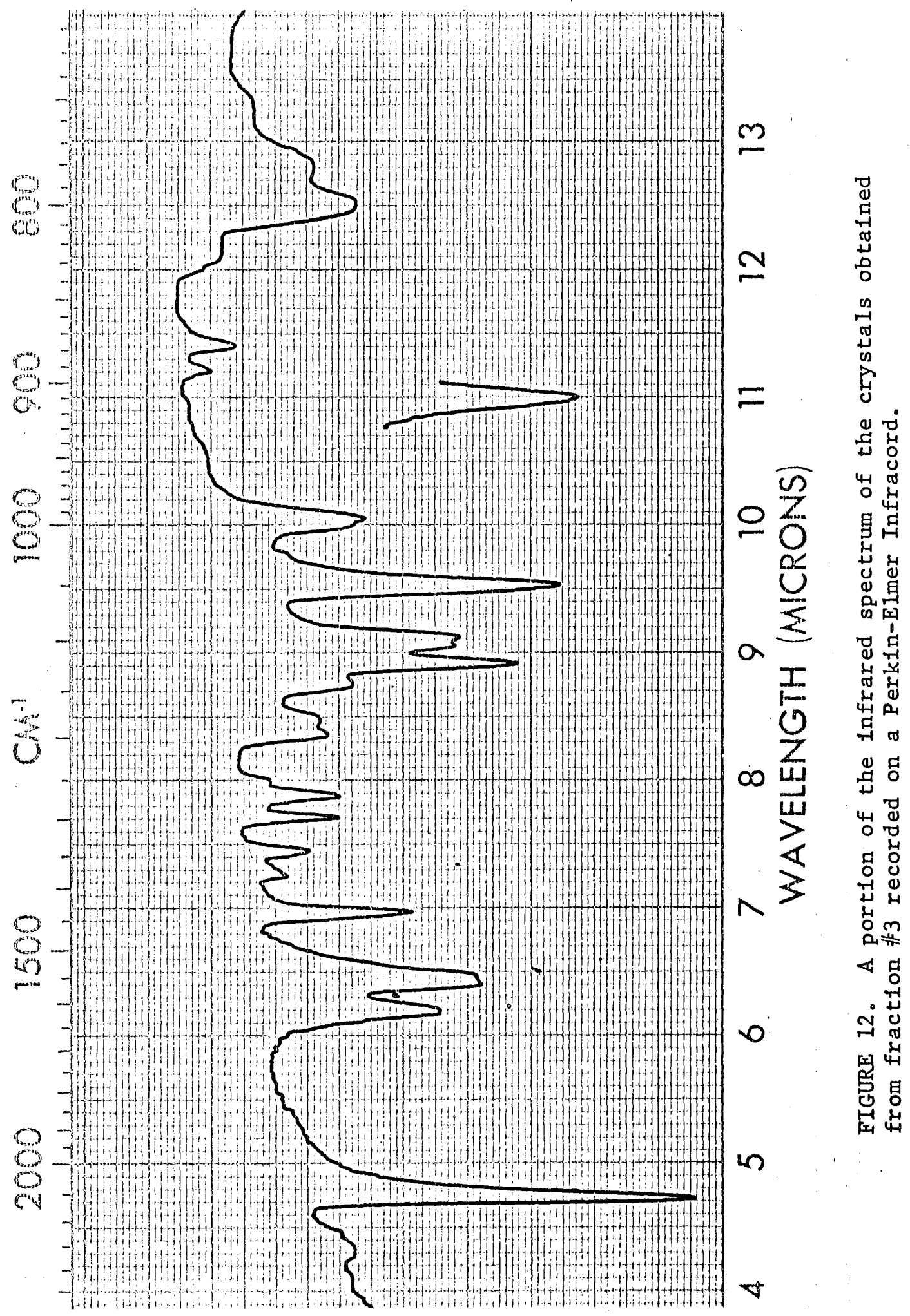


cis- $\left[\mathrm{Co}(\mathrm{en})_{2}(\mathrm{NCS}) \mathrm{Cl}\right] \mathrm{Cl}$ (see figure 8) indicated that they were not the same. The only remaining possibillty appeared to be cis$\left[\mathrm{Co}(\mathrm{en}){ }_{2}(\mathrm{NCS})\left(\mathrm{H}_{2} \mathrm{O}\right)\right] \mathrm{Cl}_{2}$ since the only other avallable ligand in the acidic aqueous solution wa $\mathrm{H}_{2} \mathrm{O}$. In order to test this possibility, cis- $\left[\mathrm{Co}(\mathrm{en})_{2}(\mathrm{NCS}) 01\right] \mathrm{Cl}$ was dissolved in water and the solution heated over a hot plate. After about one third of the solution had evaporated, it was set aside to cool. Dark red crystals (only slightly soluble in water) formed after about two hours. Baldwin and Tobe ${ }^{36}$ have demonstrated that $\mathrm{clg}^{+}\left[\mathrm{Co}(\mathrm{en})_{2} \text { (NCS)C1}\right]^{+}$aquates with retention of geometrical conflguration to cis- $\left[\mathrm{Co}(\mathrm{en})_{2}(\mathrm{NCS})\left(\mathrm{H}_{2} \mathrm{O}\right)\right]^{++}$. It was, therefore, assumed that the compound which had been prepared as described above was cis- $\left[\mathrm{Co}(\mathrm{en})_{2}(\mathrm{NCS})\left(\mathrm{H}_{2} \mathrm{O}\right)\right] \mathrm{Cl}_{2}$. Additional support for this assumption was obtained from an examination of the infrared spectrum of the compound. The spectrum recorded on the IR-12 Indicated the presence of coordinated thiocyanate, confirmed the cis configuration and differed significantly from the spectrum of the unaquated complex. A comparison of the spectrum of this compound (see figure 4) with that of the flakey orange crystals isolated from fraction 非a (see figure 3) Indicated that the two compounds were identica1.

D. The spectrum of the aquated compound differed from that of the unaquated compound in two noteworthy waya. First, an additional, moderately strong absorption peak appeared at about $715 \mathrm{~cm}^{-1}$ (see figure 5). Second, the higher frequency peak of the two in the neighborhood of $1600 \mathrm{~cm} .^{-1}$ was displaced to a lower frequency by about $35 \mathrm{~cm}^{-1}$ (see figure 6). These peaks have been assigned by Morris and 
Busch ${ }^{37}$ to the assymmetric deformation of the $\mathrm{NH}_{2}$ group.

E. The spectrum of the reddish crystals obtained from fraction \#2a (see figure 7) indicated that it was a cis compound. It appeared that it might have been contaminated by some of the first compound to crystallize from the same solution. However, a comparison with the spectrum of $\mathrm{clg}-\left[\mathrm{Co}(\mathrm{en})_{2}\right.$ (NCS)C1] C1 (see figure 8) indicated that they were the same compound.

F. A comparison of the spectrum of the green crystals, obtained from fraction $\# 2$ a by evaporating over a hot plate (see figure 9), with that of trans- $\left[\mathrm{Co}(\mathrm{en})_{2} \mathrm{Cl}_{2}\right] \mathrm{Cl}$ (see figure 10) indicated that they were Ldent1cal compounds as suspected.

G. A study of the spectrum of the red compound obtained from fraction $k_{3}$ (see figure 12) indicated that it was cig- $\left[\mathrm{Co}(\mathrm{en})_{2}(\mathrm{NCS}) \mathrm{Cl}\right] \mathrm{C1}$. Two peaks appeared around $1600 \mathrm{~cm} .^{-1}$, and in the $1100-1150 \mathrm{~cm}^{-1}$, and $870-900 \mathrm{~cm} \cdot{ }^{-1}$ regions. Only one thiocyanate absorption peak appeared in the nelghborhood of $2100 \mathrm{~cm} .^{-1}$, ruling out the clg-dithiocyanato and cis-dichloro compounds, and the peak frequencles closely matched those of the infrared spectrum of cis-[Co(en) ${ }_{2}$ (NCS)C1] CI (see figure 8).

V.II. Analysis of the Ultraviolet spectra.

Since crystals of the same compound were isolated from separate fractions eluted with, respectively, 1 and 3 molar $\mathrm{HCl}$ solutions, it was obvious that some change was occurring in at least one of the fractions after elution from the column. It was thought that an 
analysis of the ultraviolet spectra of the complexes in solution might help resolve the problem.

The ultraviolet and visible spectra of cis- and trang$\left[\mathrm{Co}(\mathrm{en})_{2} \text { (NCS)C1 }\right]^{+}$in solution have been studied by Basolo ${ }^{38}$, Shimura ${ }^{39}$, and Kuroya and Tsuchida ${ }^{40}$. Minor differences in the three reports may be due to solvent differences since Shimura and Kuroya and Tsuchida studied the spectra of the compounds in aqueous solution while Bagolo dissolved the compounds in 99 per cent methanol to avold aquation. Thus Basolo reported a broad peak at 510 millimicrong while Kuroya and Tsuchida reported a peak at 503 millimicrons in the spectrum of cis- $\left[\mathrm{Co}(\mathrm{en})_{2}\right.$ (NCS)CI ${ }^{+}$. A complication in the interpretation of this spectrum occurs in the region between 290 and 300 millimicrons where a broad inflection but no distinct peak appears. Shimura attributes the obscuring of a peak in this region to the interference of "end absorption." He has plotted theoretical peaks to compensate for this interference and thus arrived at a peak of 305 mililmicrons. Basolo reported an absorption maximum at 300 miliimicrons.

The ultraviolet spectra reported here were recorded on a Bausch and Lomb Spectronic 505 recording spectrophotometer. The spectra (see figure 13) of cle- $\left[\mathrm{Co}(\mathrm{en})_{2}\right.$ (NCS)C1] C1 freshly dissolved in water and methanol gave similar inflections but no peaks in the neighborhood of 3000 miliimicrons. However, when the water solution was allowed to stand for two days before the spectrum was again recorded (see figure 14), a sharp peak appeared at 310 millimicrons. Apparently, aquation of the complex took place during the interim. Support for this conclusion was obtained by examining the spectrum (see figure 15) of cis$\left[\mathrm{Co}(\mathrm{en})_{2}(\mathrm{NCS})\left(\mathrm{H}_{2} \mathrm{O}\right)\right] \mathrm{Cl}_{2}$ dissolved in water, which also gave a distinct 


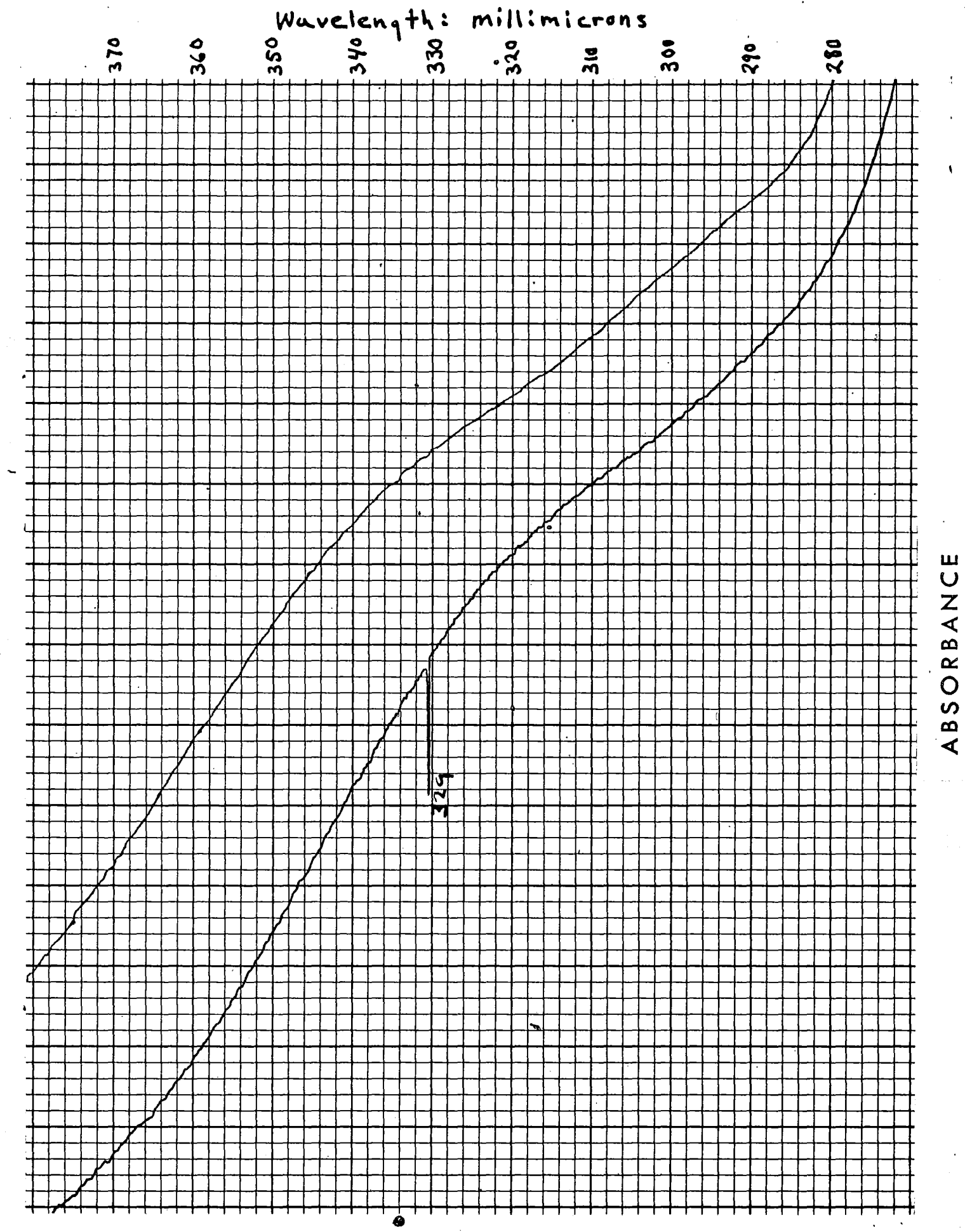

FIGURE 13. The ultraviolet spectra of c1s-[Co(en) ${ }_{2}$ (NCS)C1] C1 freshly dissolved in methanol (top curve) and water (lower curve) in the neighborhood of $300 \mathrm{millimicrons.}$ 


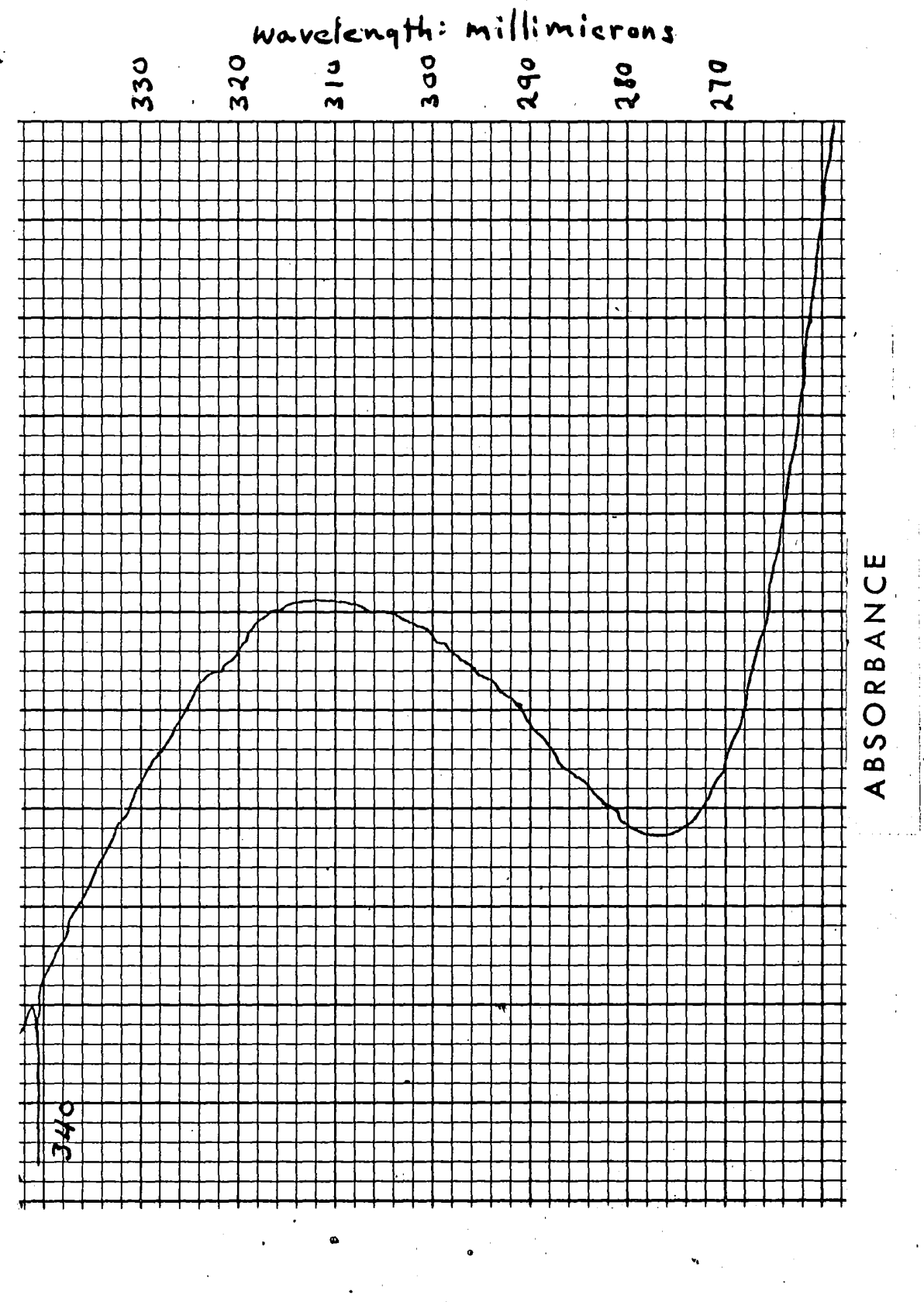

FIGURE 14. A portion of the ultraviolet spectrum of a solution prepared by dissolving in water and allowing to stand two days. 


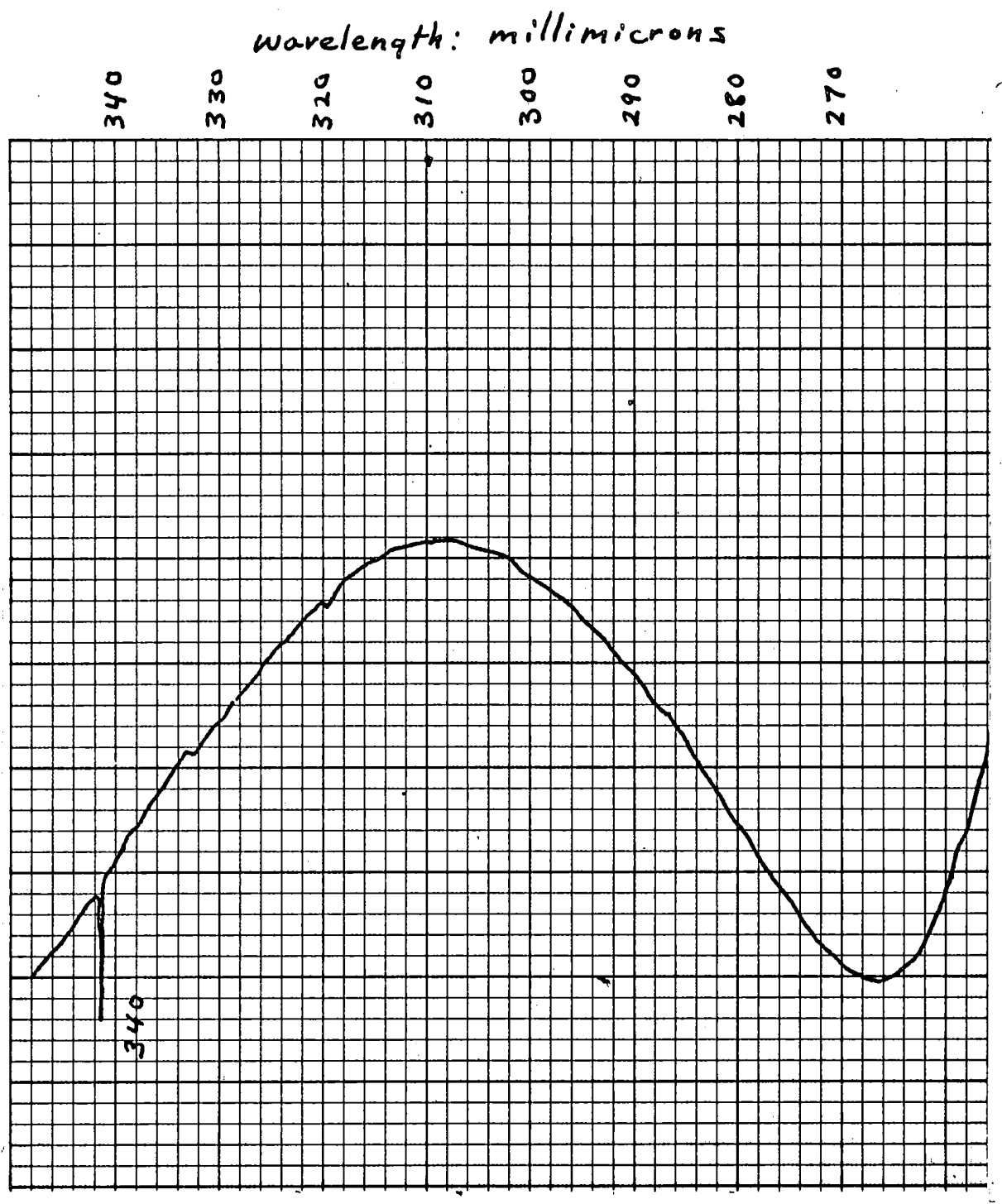

$u$
$z$
$<$
$\infty$
$\alpha$
0
$\sim$
$\infty$
$<$

FIGURE 15. A portion of the ultraviolet spectrum of c1s- $\left[\mathrm{Co}(\mathrm{en})_{2}(\mathrm{NCS})\left(\mathrm{H}_{2} \mathrm{O}\right)\right] \mathrm{Cl}_{2}$ freshly dissolved in water. 


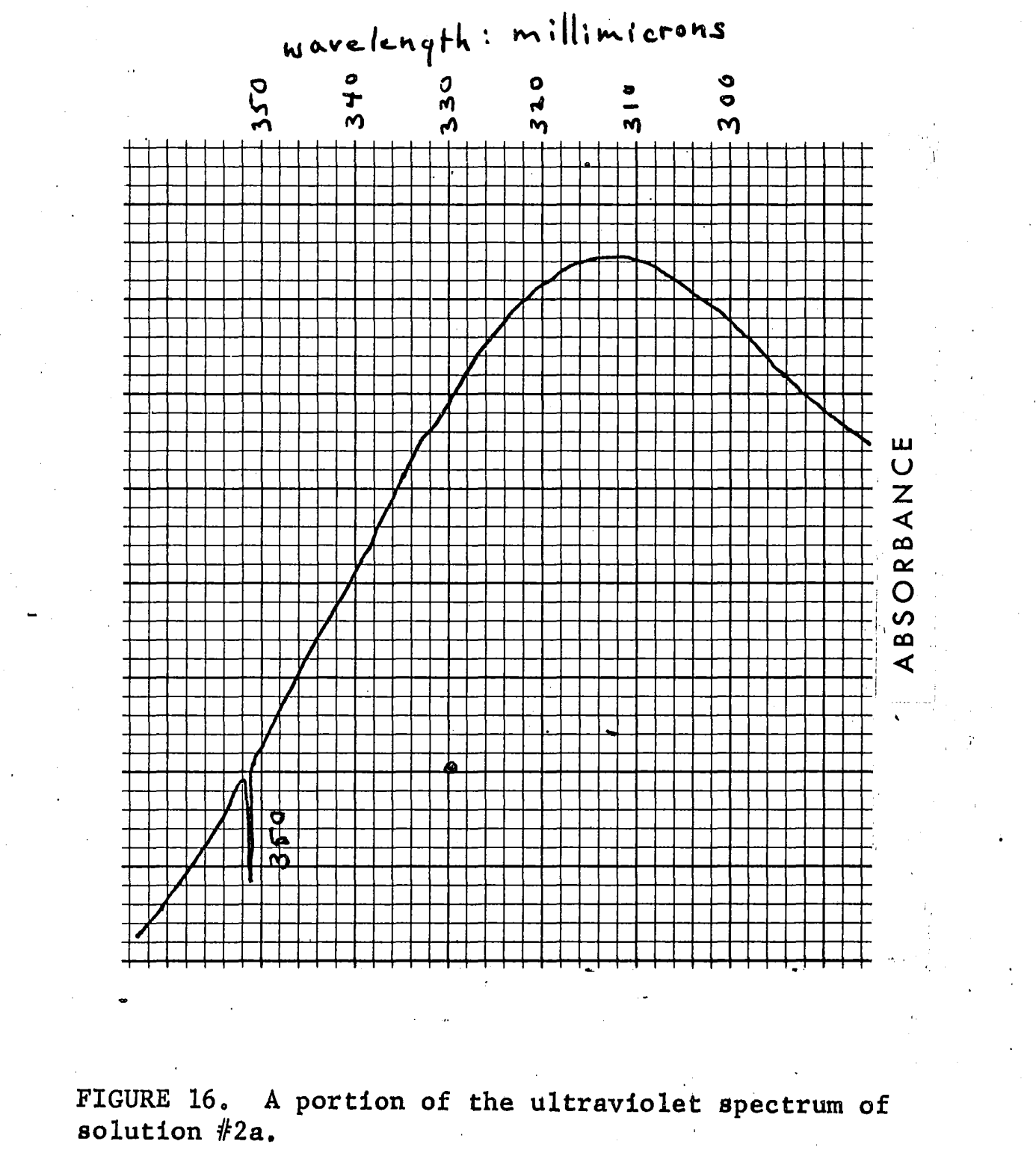




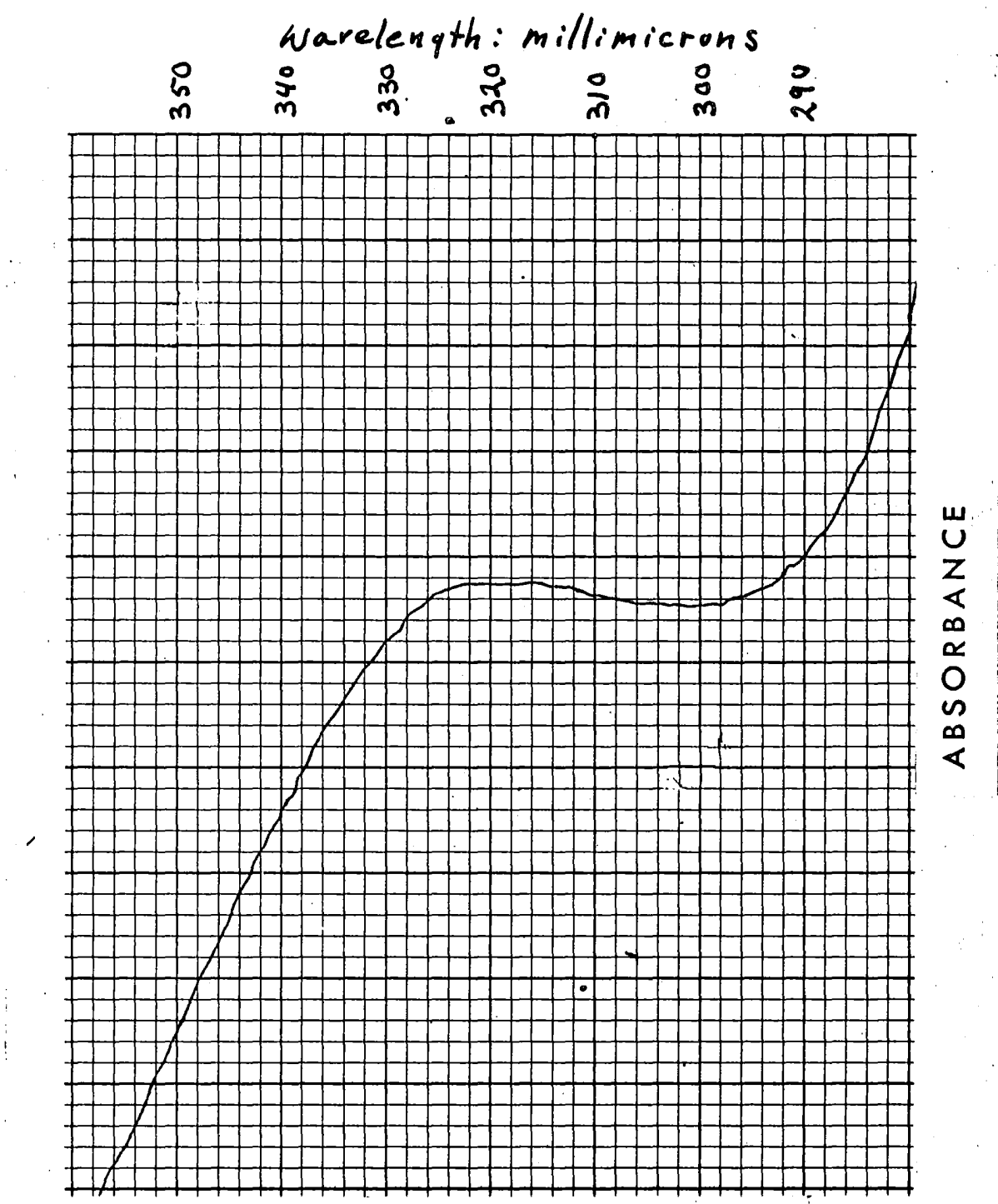

FIGURE 17. A portion of the ultraviolet spectrum of solution 非2d. 


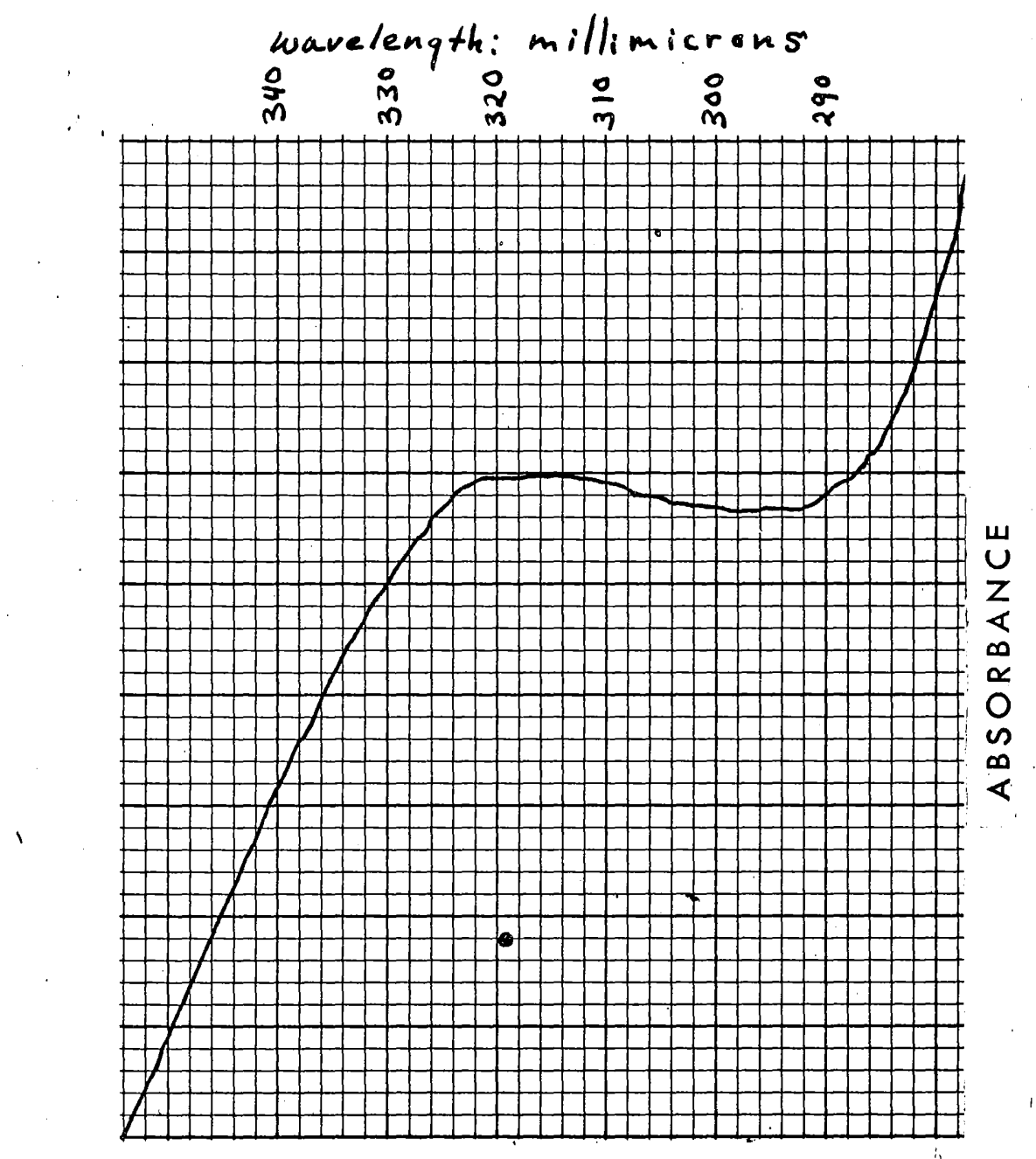

FIGURE 18. A portion of the ultravlolet spectrum of solution 非3. 
peak at $310 \mathrm{~m} 1111$ crons. The spectra of solutions 倣a (see figure 16), \#2d (see figure 17), and 13 (see flgure 18) gave definite peaks of varying depth and sharpness between 310 and 320 milificrons suggesting that different proportions of aquated and unaquated complex were present in each solution.

The spectrum of solution $/ 2 b$ gave peak at about 290 milimicrons indicating that this compound was different from those mentloned above.

VIII. Estimate of the Irane- $\left[\mathrm{Co}(\mathrm{en})_{2}\right.$ (NCs)C1 $] \mathrm{C1}$ Content of the Product Mixture

A sample of the crystals obtained from fraction \#1 was anilyzed for cobalt by an electroplating method ${ }^{41}$ (see page 47) to determine the purity and acertain a practical molecular waight, to be used in calculating the molarity of a solution of the compound. The per cent cobelt calculated for $\left[\mathrm{Co}\left(\mathrm{C}_{2} \mathrm{~N}_{2} \mathrm{H}_{8}\right)_{2}(\mathrm{NCS}) \mathrm{Cl}\right] \mathrm{Cl} 1 \mathrm{10} 19.8$, and that found was 19,7 .

Fraction 11 appeared to be pure trans- $\left[\operatorname{Co}(e n)_{2}(\mathrm{NCS}) \mathrm{CI}\right] \mathrm{cl}$ in HCI. There was no aquation of the compound on the column, and no evidence of aquation after elution. Therefore, it tas possible to estimate the concentration of this compound in the product mixture by measuring the Intensity of abgorption of the eluted solution in the ultraviolet region. The same could not be done with fractions $\$ 2$ and $\|_{3} 3$ ince they were found to be mixtures of $\mathrm{cls}-\left[\mathrm{Co}(\mathrm{en})_{2}(\mathrm{NCS}) \mathrm{Cl}\right] \mathrm{Cl}$ and its aqua derivitive, $\mathrm{dig}=\left[\mathrm{Co}(\mathrm{en})_{2}(\mathrm{NCS})\left(\mathrm{H}_{2} \mathrm{O}\right)\right] \mathrm{Cl}_{2}$.

A product mixture was prepared by reacting 8.57 gram $(0.0300$ 
mole) of trans- $\left[\mathrm{Co}(\mathrm{en})_{2} \mathrm{Cl}_{2}\right] \mathrm{Cl}$ dissolved in $12 \mathrm{ml}$. of water with 2.92 grams ( 0.0300 mole) of KSCN dissolved in $4 \mathrm{ml}$. of water, and diluting to $50 \mathrm{~m} 111111$ ters in a volumetrte flask. Thus each milliliter of diluted product mixture contained 0.000600 mole of cobalt compound asguming one cobalt atom per molecule. One mililiter of the diluted product mixture was pipetted onto each of two lon-exchang columns of Dowex $50 W-x 8$ before any cryatalization from the mixture had taken place. The first bend was entirely eluted from each column with $0.5 \mathrm{M}$ HCl and collected In flask. The fraction thus collected was diluted to 250 milliliters with 0.5 M HCl in a volumetric flask, and the per cent transmittance at the peak at 555 mi11imlerons was measured on a Basch and Lomb Spectronle 20 ultraviolet spectrophotometer.

A concentration versus absorbance curve was plotted (see figure 19) by dissolving a walghed amount of the analyzed trans$\left[\mathrm{Co}(\mathrm{en})_{2}\right.$ (NCS)C1]C1 in $0.5 \mathrm{M} \mathrm{HC1}$ and measurlng the absorbance for different dilutione (see table $\mid 2$ ). The concentration of the compound in solution 11 was read from the plot, and this value was used to estimate the fraction of trang- $\left[\mathrm{Co}(\mathrm{en})_{2}\right.$ (NCS)C1]c1 in the product mixture (see table $\$ 3$ ).

The average value of the mole par cont of trans$\left[\mathrm{Co}(\mathrm{en})_{2}\right.$ (NCS)Cl]Cl found in the partLcular reaction mixture was $49 \%$. 


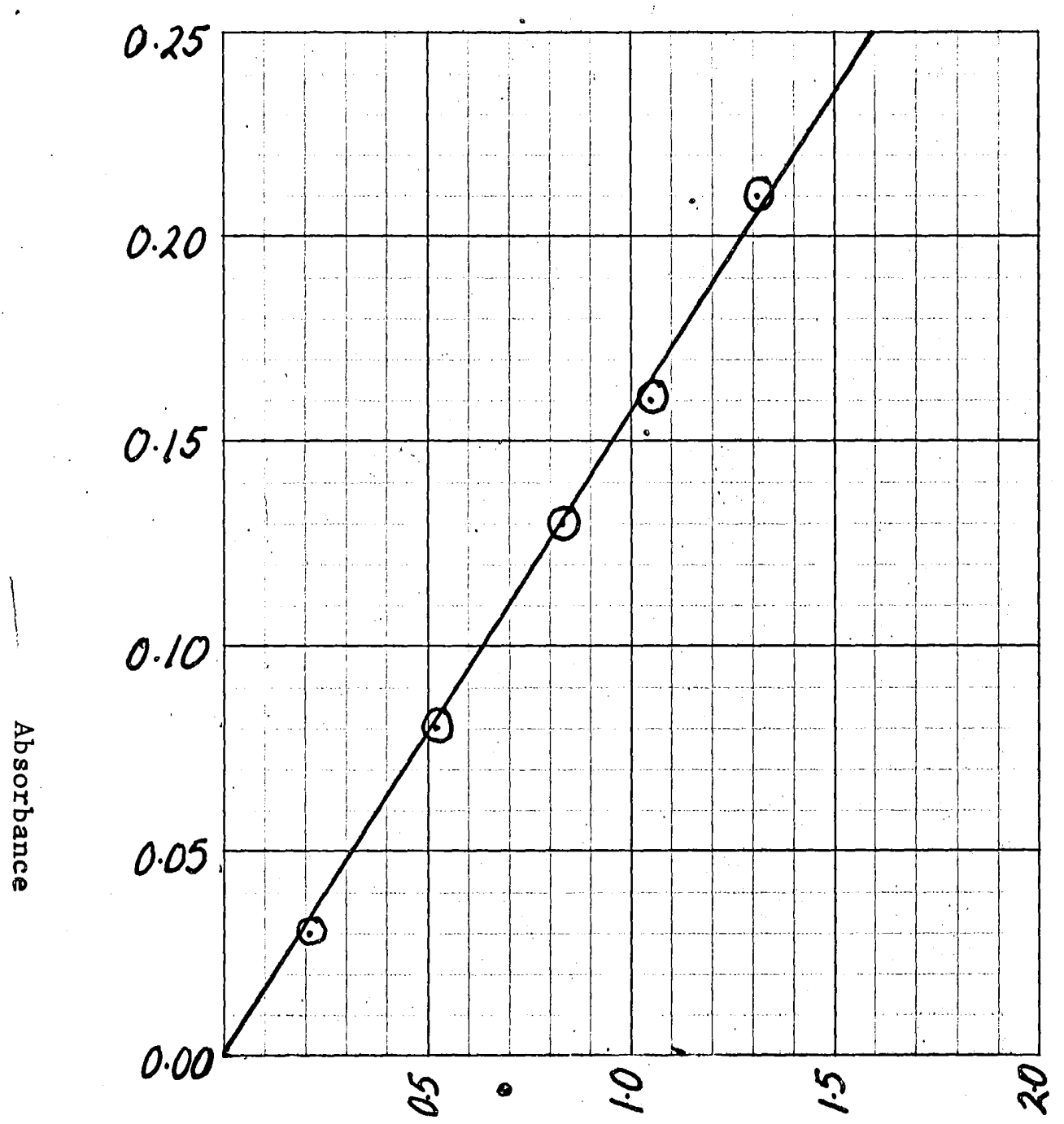

Concentration: molex/11ter $\times 10^{3}$

FIGURE 19: Concentration versus absorbance for trans- $\left[\mathrm{Co}(\mathrm{en})_{2}(\mathrm{NCS}) \mathrm{Cl}\right] \mathrm{Cl}$ dissolved in $0.5 \mathrm{M} \mathrm{HCl}$. 
TABLE 2: ABSORBANCE MEASUREMENTS AT VARIOUS CONCENTRATIONS FOR IRANS- $\left[\mathrm{Co}(\mathrm{en})_{2}\right.$ (NCS)C1] CI IN $0.5 \mathrm{M}$ HC1 SOLUTION

\begin{tabular}{lllll}
$\begin{array}{l}\text { Concentration } \\
\text { grams/1iter }\end{array}$ & $\begin{array}{l}\text { Concentration } \\
\text { moles/11ter X }\end{array} 0^{3}$ & $\begin{array}{l}\text { Per cent } \\
\text { Transmittance }\end{array}$ & Absorbance \\
\cline { 2 - 3 } 0.781 & 2.62 & 38 & 0.42 \\
0.391 & 1.31 & 62 & 0.21 \\
0.312 & 1.05 & 69 & 0.16 \\
0.249 & 0.84 & 74 & 0.13 \\
0.156 & 0.52 & 83 & 0.08 \\
0.063 & 0.21 & 94 & 0.03
\end{tabular}

TABLE 3: DATA FOR UNKNOWN SOLUTIONS

\begin{tabular}{|c|c|c|c|c|}
\hline $\begin{array}{l}\text { Per cent } \\
\text { Transmittance }\end{array}$ & Absorbance & $\begin{array}{l}\text { Concentration } \\
\text { moles/liter }\end{array}$ & $\begin{array}{l}\text { Concentration } \\
\text { moles } / 250 \mathrm{~m} 1 \text {. }\end{array}$ & $\begin{array}{l}\text { Mole } \\
\% \text { in } \\
\text { mixture }\end{array}$ \\
\hline 66 & 0.18 & $1.15 \times 10^{-3}$ & $2.87 \times 10^{-3}$ & 48 \\
\hline
\end{tabular}

IX. Analysis for Cobalt by Electrodeposition

Two electrodeposition methods were used to analyze for cobalt. Trans- $\left[\mathrm{Co}(\mathrm{en})_{2} \mathrm{Cl}_{2}\right] \mathrm{Cl}$ was analyzed by the method of Shreiber. ApproxImately 0.2 grams of the complex was welghed out and dissolved in water In a beaker. About 2 milifiters of ethylenediamine was added as an electroplating agent, and a potential of about 10 volts was applied through the solution between platinum electrodes to obtain a current of about 0.2 amperes. When the color of the complex had disappeared (3-4 hours), the cathode was rinsed in acetone and air-dried before weighing. The per cent cobalt calculated for trans- $\left[\mathrm{Co}(\mathrm{en})_{2} \mathrm{Cl}_{2}\right] \mathrm{Cl}$ is 20.6, and that found was 20.5

An attempt was made to analyze trans- $\left[\mathrm{Co}(\mathrm{en})_{2}\right.$ (NCS)C1] C1 by the 
above method but a low value was obtalned (12 per cent as opposed to 19.8 per cent calculated). A method was, therefore, adapted from Dale and Banks ${ }^{41}$ in which the sample is vigorously oxldized before electrolysis. Approximately 0.2 grams of the compound was dissolved in 20 mill11ters each of concentrated nitric and coneentrated oulfurle aclds. The resulting solution was bolled over a Bungen burner, with intermittant addition of nitric actd, to near drynes: Twenty millilters more of each actd was added and the evaporation repeated. The restdue was disgolved in mintoun of watex and the solution again evaporated to fumes of $\mathrm{SO}_{2}$. Thts step was repeated two or three nore times, The violet residue was then dissolved In water and ransferred quantitatively to an lectroplating beaker. About 20 mill111ters of 6 M amondum hydroxide and 2 grams of sodiun bloulstite was added. The resulting soluthon electrolyzed between platinum electrodes. The eurrent was malntatned at $2-4$ amperes. When the color had completely disappeared from the soluthon, plating was asoumed to be complete, and the eathode was rinsed in acetone and air-dried before welghing. The per cant cobalt calculated for $\left[\operatorname{Co}(e n)_{2}(\right.$ NCs $)$ C1 $]$ C1 is 19.8 and that found was 19.7 .

In the anaiysis described above, Fischer Electroanalyzer was used as a souree of voltage. 


\section{DTSCUSSION OR THE EXPERTMENTAL RESULTS}

A number of coneluslons appear to be warranted by the expertmental results reported in the previous section. The flrat fraction to be eluted from the lon-exchange colun has been Identifled by Infrared spectra and confinded by cobalt analysis as trans- $\left[\mathrm{Co}(\mathrm{en})_{2}(\mathrm{MCS}) \mathrm{CI}\right]^{+}$. This is hardy furprising ince the crang-ehlorothiocyanato compound erystallizes from the product mittuze studied here, and, In all previous Lon-exchange separations of geometric loomers of coordination compounds, the trans Lomer has been eluted fixst.

The Identlfication of the other fractions off the lon-exehange colum wa lesa stralghtforward. The infrared spectra Indicate that als- $\left[\mathrm{Co}(\mathrm{an})_{2}(\mathrm{NCS}) \mathrm{d}\right] \mathrm{cl}$ orystallized from both fraction t2a and fraction \#3, and yet, both bands on the colum could not have the same composltion or no band separation would heve occurred. The logical explanation 18 that band 20 $48 \mathrm{ds}\left[\mathrm{Co}(\mathrm{en})_{2}(\mathrm{NCS}) \mathrm{CI}\right]^{+}$, and band $\$ 3$ is

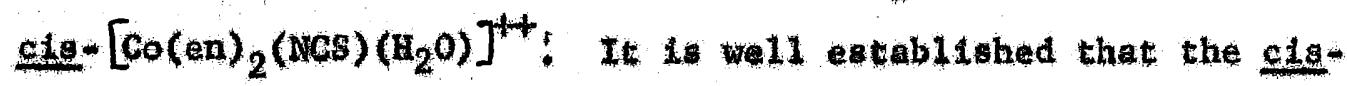
chlorothlocyanto eompound aqutes readliy, and it is highly improbable that the diposittve lon would elute more rapldiy than the monopositive

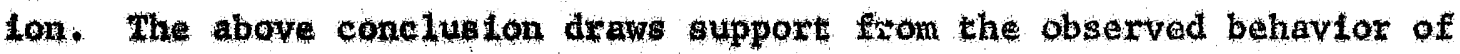
band $12 a$ on the colum and an analys ls of the witravtolet spectra of the eluced iractlons. It may be recalled that a new band was left

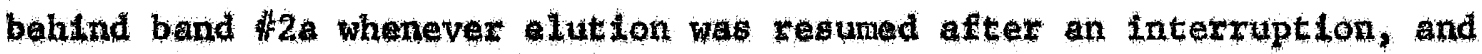
that the new band was eluted at the same rate a band 13 . In addition, the area between band $2 a$ and band 3 not occupled by another band was pink rather than the off-white color of the resin. Such behavior may 
be explained by aquation of the material in band $\left.\right|^{2 a}$. The fact that the non-banded region of the resin betwean band 非a and band 非 3 was pink suggests that aquation of $\mathrm{cis}-\left[\mathrm{Co}(\mathrm{en})_{2}(\mathrm{NCS}) \mathrm{C1}\right]^{+}$in band $\#_{2 a}$ occurred continually during elution. When elution was resumed after an Interruption, the dipositive aquated complex formed during the Interim remained behind as a discrete band. The fact that a band thus formed eluted at the same rate as the third band is support for the contention that the two bands were the same material, namely cis- $\left[\mathrm{Co}(\mathrm{en})_{2}(\mathrm{NCS})\left(\mathrm{H}_{2} \mathrm{O}\right)\right]^{++}$. That no $\mathrm{cls}-\left[\mathrm{Co}(\mathrm{en})_{2}(\mathrm{NCS})\left(\mathrm{H}_{2} \mathrm{O}\right)\right] \mathrm{Cl}_{2}$ was obtained from fraction 3 can be explained by rechlorination of the aquated complex after elution in the 3 M HCl solution. Likewise, the fact that crystals of the aquated complex were obtained from fraction 非 2 a can be explatined by aquation of $\mathrm{cls}-\left[\mathrm{Co}(\mathrm{en}) \mathrm{N}_{2}\right.$ (NCS)C1]C1 after elution in the 1 M HCl solution. The ultraviolet spectra of the eluted fractions $\|^{2} 2 a$, 非 $2 d$, and 非 3 indicate that aquated complex was present in each. Each fraction gave peak at or very near the peak wavelength of $\mathrm{cls}-\left[\mathrm{Co}(\mathrm{en})_{2}(\mathrm{NCS})\left(\mathrm{H}_{2} \mathrm{O}\right)\right] \mathrm{Cl}_{2}$ in water at 310 milificrons. $\mathrm{Cls}-\left[\mathrm{Co}(\mathrm{en})_{2}\right.$ (NCS)(C1)]C1 gives no distinct pealt in the same region. The eluted fractions $\|^{2 a}$ and $\|_{3}$ must, therefore, be mixtures of the aquated and unaquated complex.

Michelfeld ${ }^{7}$ also observed the occurrence of aquation on an ionexchange column. In the separation of $\mathrm{cis}^{-}$and $\operatorname{trans}-\left[\mathrm{Co}(\mathrm{pn})_{2} \mathrm{Cl}_{2}\right] \mathrm{cl}$ by ion-exchange chromatography he found that no aquation occureed during continuous elution but did occur during the stationary period when elution was interrupted. In the work reported here, aquation 
proceeded during both interrupted and uninterrupted periods of elution and it was not readily observable whether or not such aquation took place more rapidly during a tationary period.

It would be interesting to determine whether aquation occurs on lons adsorbed on the surface of resin particles as well as in solution. Such a determination could be made by mixing aqueous solutions of the compound with varying amounts of resin and acertaining any rate dependence on the resin concentration. The rate of the reaction could be followed conventently by changes in the ultravlolet spectra. Catalysis by ton exchangers is not at all uncommon, and Helffer1eh 42 devotes complete chapter to the subject in his book on ion exchange. Determination of the rate dependence on the resin concentfation might help to elucidate the mechanism of aquation. Adsorption on the resin would naturally hinder access to certaln sites on the complex lon.

When the second fraction, which has been identifled as a mixture

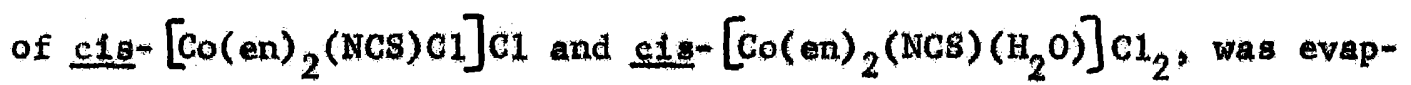
orated over a hot plate, green crystals of trans- $\left[\mathrm{Co}(\mathrm{en})_{2} \mathrm{Cl}_{2}\right] \mathrm{Cl}$ were obtained. Evidently, the thermal energy supplied was sufficient to cause the thiocyanato ligand to be replaced by a chloro ligand in the 1 M HCl solution used as eluent forming eis- $\left[\mathrm{Co}(\mathrm{en})_{2} \mathrm{Cl}_{2}\right]^{+}$which then Isomerized to the trans tsomer which is the more stable form in actd solution,

Under conditions of room temperature evaporation, no erystals of dichloro or dithlocyanato complexes were obtained. This does not guarantee that these compounds were entirely absent from the product mixture. There is always the possibility that one or more of these 
compounds could elute with one of the major fractions and be so

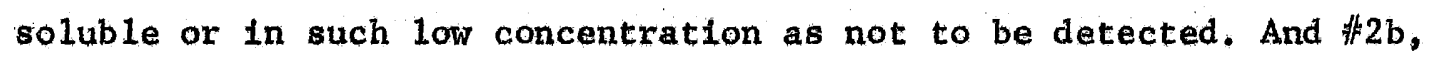
which separated from la $^{2}$ even during an uninterrupted elution, was never positively identifled. Despite these possibilities, it is quite likely that any of the dichloro or dithlocyanato compounds, if present, were there only in very low concentration so that it may be cautiously concluded that an essentially $1: 1$ reaction took place between trans- $\left[\mathrm{Co}(\mathrm{en})_{2} \mathrm{Cl}_{2}\right] \mathrm{Cl}$ and thlocyanate fon.

In a typical product mixture, trans- $\left[\mathrm{Co}(\mathrm{en})_{2}\right.$ (NCS)C1]C1 was found to constitute 49 per cent of the products. The composition of the remainder of the product mixture is somewhat in doubt. The primary constituents have been shown to be cis- $\left[\mathrm{Co}(\mathrm{en})_{2}(\mathrm{NCS}) \mathrm{Cl}\right] \mathrm{C1}$ and cis$\left[\mathrm{Co}(\mathrm{en})_{2}(\mathrm{NCS})\left(\mathrm{H}_{2} \mathrm{O}\right)\right] \mathrm{Cl}_{2}$ and, therefore, the total cis isomer content, both aquated and unaquated, may be estimated at near 50 mole per cent. The remaining constituents were present only in very small quantity and were not ldentifled. They include the material in the first rapidly eluted band (probab1y a neutral compound), band $\# 2 b$, the 14ght-pink band remaining after elution of band 3 (probably the dlaquated, tripositive Lon), and the dark compound which adsorbs strongly to the resin at the top of the column.

It should be polnted out that the conclusions drawn above are valid, in the strictest sense, only for the reaction and separation carried out under the particular imposed conditions. Perhaps, for example, significantiy different results would have been obtained had certain other eluting solutions been used. It is thought, however, that the results, for the most part, reflect accurately on the true 
composition of the product mixture. Had aquation of the trans isomer taken place, the solution eluted between band \#1 and band $\# 2$ a would have been colored but it was completely colorless. Any equilitbration of the cis and trans isomers would have resulted in a spreading and running together of bands $\equiv_{1} 1$ and $\#_{2} \mathrm{a}$, but this was likewise not observed. Therefore, it is assumed that the mole per cent of this compound was not affected by the separation procedure. That only pure trans- $\left[\mathrm{Co}(\mathrm{en})_{2}\right.$ (NCS)C1]C1 was obtained from the eluted fraction shows Ion-exchange chromatography to be a convenient method of isolating the pure trans isomer from the product mixture; it is quite soluble relative to the cls isomer and not readily isolated by evaporation of the mixture.

It was not possible to estimate the cis- $\left[\mathrm{Co}(\mathrm{en})_{2}\right.$ (NCS)C1]c1 concentration of the product mixture because of the readiness with which the compound aquates. It must be higher than would appear from the experimental results, however. The product mixture was diluted with water before being poured onto the column, and some aquation must certainly have occurred on the column before separation of the aquated and unaquated complexes causing the amount of aquated complex to appear erroneously high. Such complications could be avolded by finding a good eluting solvent in which aquation does not occur. It would be risky to speculate on a mechanism for the reaction studied here on the basis of the experimental results. There are too many complicating factors. In aqueous solution the reaction may proceed through preliminary aquation and then isomerization of the 
aquated complex before attack by thiocyanate. A number of exchange reactions proceed through these initlal reactions fucluding the isomerization of clg- $\mathrm{Co}(\mathrm{en})_{2} \mathrm{Cl}_{2}{ }^{+}$to the trans form. ${ }^{43}$ If one or both of these preliminary reactions took place en route to the final product, then the data reported here would be of little use In suggesting a mechanism. Even if the reaction involved only the staxting compound and thiocyanate little could be concluded without rate data and even then the problem is complicated. There are more sites for approach by nucleophillic reagent in an octahedral system than in the simpler tetrahedral structure and retention and Inversion of configuration can take place in both the $\mathrm{SN}-1$ and SN-2 mechanisms with octrahedral complexes. In order to avoid the problem of aquation discussed above, brown and Nyholm 44 studied the reaction between $\mathrm{cls}-\left[\mathrm{Co}(\mathrm{en})_{2} \mathrm{Cl}_{2}\right]^{+}$and thiocyanate in methano1 solution. The results were found to be consistent with elther an SN-1 or SN-2 mechanism.

There is one remaining point, concerning the interpretation of the infrared spectra, whlch deserves brlef mention here. It was observed that an absorption peak appeared at $715 \mathrm{~cm}^{-1}$ in the spectrum of cis- $\left[\mathrm{Co}(\mathrm{en})_{2}(\mathrm{NCS})\left(\mathrm{H}_{2} \mathrm{O}\right) \mathrm{Cl}_{2}\right.$ which was not present in the spectrum of the unaquated compound (see figure 5). This peale may be due to vibration of the bond betwean cobalt and Ilgand water. 
SUMMARY

The product mixture resulting from equimolar reaction of trans$\left[\mathrm{Co}(\mathrm{en})_{2} \mathrm{Cl}_{2}\right] \mathrm{Cl}$ and thiocyanate was separated into its components on an ion-exchange column. The major components were then identified by means of infrared and ultraviolet spectroscopy. The product mixture was found to contain cis- and trans- $\left[\mathrm{Co}(\mathrm{en})_{2}(\mathrm{NCS}) \mathrm{C1}\right] \mathrm{C1}$ and $\underline{\mathrm{cis}-}\left[\mathrm{Co}(\mathrm{en})_{2}(\mathrm{NCS})\left(\mathrm{H}_{2} \mathrm{O}\right)\right] \mathrm{Cl}_{2}$. The trans compound was found to comprise 49 mole per cent of a typical product mixture, and since other products were present only in very sma11 concentration, the combined $\mathrm{Cls}-\left[\mathrm{Co}(\mathrm{en})_{2}(\mathrm{NCS}) \mathrm{Cl}\right] \mathrm{C1}$ and $\mathrm{cig}-\left[\mathrm{Co}(\mathrm{en})_{2}(\mathrm{NCS})\left(\mathrm{H}_{2} \mathrm{O}\right)\right] \mathrm{Cl}_{2}$ content was estimated at roughly 50 mole per cent.

The trans isomer was eluted first, the unaquated cis 1somer second, and the equated c1s Isomer third from the lon-exchange column. This is the order predicted on the basis of relative charge and dipole moment. Aquation of c1g- $\left[\mathrm{Co}(\mathrm{en})_{2} \text { (NCS)C1 }\right]_{\text {was observed to }}^{+}$ occur on the column as well as in the eluted solution. In addition, rechlorination of the aquated compound was found to occur in the eluted fractions so that, after elution, the second and third fractions were mixtures of the aquated and unaquated cis complexes. 


\section{BIBLIOGRAPHY}

1. E. L. King and E. B. Dismukes, J. Am. Chem. Boc., 74, 1674 (1952).

2. E. L. King and R. R. Walters, J, Am. Chem. Soc., 74,4417 (1952).

3. M. Mori, M. Shibata, and J. Azama, Mipon. Kagaku. Zasshi., Z6, 1003 (1955) as cited in C. A., 52, 116401 .

4. M. Mor1, M. Shibata, and M. Nanasawa, Bu11. Chem. Soc. Japan, 29. 947 (1956).

5. J. T. Hougen, K. Schlug, and E. L. KIng, J. Am. Chem. Soc., 79, 519 (1957).

6. P. N. Dimotakis and C. D. Myrat, J. Inorg. Nuc1. Chem, 21, 184 (1961).

7. T. A. Michelfeld, Ph. D. Thesis, University of Nebraska, 1967.

8. A. Werner, Lieb. Ann., 386, 139 (1912).

9. F. Helfferlch, "Ion Exchange," McGraw-Hi11, New York, 1962, p. 1.

10. F. Helffer1ch, op. c1t., p. 2.

11. J. A. KItchener, "Ion-Exehange Resins," Methuen, London, 1957, p. 1.

12. J. A. Kitchener, ibid.

13. J. A. Kitchener, op. c1t., p. 11 .

14. B. A. Adams and E. L. Holmes, J. Soc. Chem. Ind. (London), 54, 1T (1935) as cited in F. Helfferich, op. cit., p. 4.

15. F. Helffertch, op. c1t., p. 35 .

16. F. Helfferich, op. cit., p. 27 .

17. F. Helfferich, op. cit., p. 438.

18. P. Faust and J. V. Quagliano, J. Am. Chem. Soc., 76, 5346 (1954).

19. M. M. Stimson and M. J. O'Donne11, J. Am. Chem. Soc., 74, 1805 (1952).

20. P. E. Merritt and S. E. Wiber1y, J. Phys. Chem., 59, 55 (1955).

21. M. M. Chamberlain, and J. C. Bailar, J. Am. Chem. Soc., 82, 1521 (1960). 
22. M. L. Morris and D. H. Busch, J. am. Chen. Soc., 82, 1521 (1960).

23. M. E. Baldwin, J. Chem. Soc., 4369 (1960).

24. J. M. Riggs and E. Sherwin, J. Inorg. Nucl. Chem., 27 (3), 653 (1956).

25. M. E. Baldwir and M. L. Tobe, J. Chem. Soc., 4275 (1960).

26. M. M. Chamberlain, and J. C. Bailar, op. cit, p, 6415.

27. P. N. Dimotakis and C. D. Myrat, op. cit., p. 184.

28. M. E. Baldwin and M. L. Tobe, op. cit., p. 4275.

29. J. C. Bailax Jr., INORGANIC SYNTHESES, 2, 223 (1946).

30. R. S. Schreiber, M. S. Thesis, University of Nebraska, 1959.

31. Jorgensen, J. prakt. Chem., 39, 1 (1889) as c1ted in J. C. Ballar, "Chemistry of the Coordination Compounds," Reinhold, Baltimore, 1956, p. 301 .

32. M. L. Morris and D. H. Busch, op. cit., p. 1524.

33. M. M. Chamber lain and J. C. Bailax, op. c1t. p. 6415.

34. M. E. Baldwin, op. cit., p. 4373 .

35. M. M. Chamberlain and J. C. Ballar, op. c1t. p. 6413.

36. M. E. Baldwin and M. L. Tobe, op. cit., p. 4277.

37. M. L. Morris and D. H. Busch, op. c1t., p. 1523.

38. F. Basolo, J. Am. Chem. Soc., 72, 4393 (1950).

39. Y. Shimura, J. Am. Chem. Soc, 73,5079 (1951).

40. K. Kuroya and R. Truchida, Bul1. Chem. Soc, Japan, 15, 427 (1940) as cited in J. C. Bailar, op. cit., p. 295.

41. J. M. Dale and C. V. Banks, "Treatise on Analytic Chemistry" (J. M. Kolthoff and Philip J. Elving, eds.), Interscience Pub1ishers, New York, 1962. Part 2, II, p. 363.

42. F. Helfferich, op. cit. pp. 519-549.

43. F. Basolo and R. G. Pearson, "Mechan1sms of Inorganic Reactions," John Wiley, New York, 1960, p. 125.

44. D. D. Brown and R. S. Nyholm, J, Chem, Soc., 2696 (1953). 